\title{
Municipal Solid Waste Incineration Ash-Incorporated Concrete: One Step towards Environmental Justice
}

\author{
Jiaqi Li
}

check for updates

Citation: Li, J. Municipal Solid Waste Incineration Ash-Incorporated Concrete: One Step towards Environmental Justice. Buildings 2021, 11, 495. https://doi.org/10.3390/ buildings11110495

Academic Editors: Xi Jiang, Pawel Polaczyk, Rui Xiao and Wei Hu

Received: 20 August 2021

Accepted: 3 October 2021

Published: 20 October 2021

Publisher's Note: MDPI stays neutral with regard to jurisdictional claims in published maps and institutional affiliations.

Copyright: (C) 2021 by the author. Licensee MDPI, Basel, Switzerland. This article is an open access article distributed under the terms and conditions of the Creative Commons Attribution (CC BY) license (https:// creativecommons.org/licenses/by/ $4.0 /)$.
Lawrence Livermore National Laboratory, 7000 East Avenue, Livermore, CA 94550, USA; li88@1lnl.gov

\begin{abstract}
Municipal solid waste and cement manufacture are two sources of environmental justice issues in urban and suburban areas. Waste utilization is an attractive alternative to disposal for eliminating environmental injustice, reducing potential hazards, and improving urban sustainability. The re-use and recycling of municipal solid waste incineration (MSWI) ash in the construction industry has drawn significant attention. Incorporating MSWI ash in cement and concrete production is a potential path that mitigates the environmental justice issues in waste management and the construction industry. This paper presents a critical overview of the pretreatment methods that optimize MSWI ash utilization in cement/concrete and the influences of MSWI ash on the performance of cement/concrete. This review aims to elucidate the potential advantages and limitations associated with the use of MSWI ash for producing cement clinker, alternative binder (e.g., alkali-activated material), cement substitutes, and aggregates. A brief overview of the generation and characteristics of MSWI ash is reported, accompanied by identifying opportunities for the use of MSWI ash-incorporated products in industrial-scale applications and recognizing associated environmental justice implications.
\end{abstract}

Keywords: MSWI ash; cement; alkali-activated material; environmental justice; circular economy; sustainability

\section{Introduction}

Urbanization has resulted in environmental issues (e.g., pollutions and climate change) and unfair distribution of environmental benefits and burdens to different types of populations (also known as environmental inequity/injustice) [1]. Environmental justice has brought the public's significant attention since the 1980s [2]. Many worldwide academic and governmental studies have been carried out to evaluate the correlation between factors (i.e., racial-ethnic group, poverty, and age) and exposed industrial pollutions [3-6]. Recent environmental justice studies have focused on ascertaining the disproportionated exposures of low-income minorities to air pollution, waste treatment, and disposal facilities $[7,8]$. A significant number of pieces of evidence have been unveiled: environmental hazard disproportionately affects the low-income and people of color (POC, including but not limited to Black and Hispanic American) in the United States (US) [9,10].

Waste sites (disposal, storage, and treatment facilities) have been recognized as the primary sources of environmental injustice in many regions (United Kingdom, Europe, and North America) [11]. Although the health concerns around waste sites in POC neighborhoods have been well-documented [12-15], substantial solutions to dismantling the barriers of environmental justice have not been well-established. The management of municipal solid waste (MSW) in the US has significant impacts on environmental justice. Case studies in Southern Texas [7,14-16] unveiled that MSW sites have been historically and predominantly located in/by POC neighborhoods and schools. The disposal of MSW has posed toxicological risks (emissions of hazardous compounds, e.g., landfill gas produced by bio-degradation) and odor nuisance [17]; the failure or disfunction of air pollution control (the collection of fine particles from MSW incineration) in waste-to-energy plants has posed 
pneumological risks to land proximity regions [18]; the landfilling of municipal solid waste incineration (MSWI) ash may contaminate water and soils by toxic leachates [19].

Unfortunately, the substantial dismantling of the barriers of environmental justice has not been accomplished. Besides many intensively discussed political reasons [14-16] (which are out of the interest of this review), the difficulty in environmental equity may be explained by one fact: middle-class people have more budgets to relocate-their mobility makes them less vulnerable to environmental issues than the poor [20]. Nonpolitical and technical solutions to resolve environmental injustice are necessary and urgent. Technical solutions to the re-use and recycling of MSWI ash are critical to mitigating environmental injustice.

The global generation of MSW is over 2 billion tons (Gt) per year, while the MSW recycling rate is still low [12]. For example, in the US, 300 million metric tons (Mt) of urban wastes are landfilled annually, but only $\sim 30 \mathrm{Mt}$ is incinerated with energy recovery in waste-to-energy plants. After metal separation, $\sim 7 \mathrm{Mt}$ of MSWI ash is generated yearly in the US [21]. With the rapid urbanization and population growth, the growth in the MSW generation is inevitable. The appropriate utilization of MSWI ash in the circular economy is the key to mitigating MSW-related environmental injustice and promoting urban sustainability.

The construction industry is the only sector that is comparable to the volume of MSWI ash and could match a potential market for MSWI ash utilization. Concrete is the second most used material by mass, just after water. The global production of concrete is $\sim 26 \mathrm{Gt} /$ year [22]. The US and global productions of Portland cement (PC, the primary binder of concrete) are $\sim 100 \mathrm{Mt}$ and $4100 \mathrm{Mt}$ per year, respectively [23]. The concrete industry contributes to $\sim 9 \%$ global anthropogenic $\mathrm{CO}_{2}$ emission yearly (primarily from cement manufacture), and the mass of material flows-over $30 \mathrm{Gt} /$ year of raw materials are quarried $[24,25]$. The local raw materials extraction for cement and concrete production has significant environmental and health impacts on the low-income or POC populations $[25,26]$. The utilization of MSWI ash in concrete production may mitigate the environmental justice issues from both ends.

Recent studies have suggested that MSWI ash can be used to produce concrete, brick, and other construction materials with or without pretreatment of MSWI ash [27-30]. The heavy metals (HMs, e.g., $\mathrm{Zn}, \mathrm{Ni}$, and $\mathrm{Cr}$ ) in raw MSWI ash can be immobilized in concrete or removed in further processing before mixing into concrete [31]. Note that the HMs content of MSWI ash depends on many factors (e.g., waste sources, separation, and processing conditions) [31]. The mechanical performance of MSWI ash incorporated concrete, and the leaching behaviors of the ash and concrete have been reported [32-34]. Existing articles are mainly case studies of the mechanical performance and environmental impacts of MSWI ash-incorporated cement-based materials [35,36]. Oftentimes, different studies reported contrary results, simply due to different cement types [37] and the compositional and structural variability in MSWI ash [38]. Existing reviews basically have summarized ash pretreatment techniques, ash leachability, or simply mechanical properties of ashincorporated concrete $[31,33,34,39,40]$. Few reviews have discussed cement-ash interaction mechanisms, resources management, or the feasibility of ash pretreatment in practice. Existing literature may not be suitable for experts in environmental engineering, environmental justice, and cement chemistry to understand the ash-cement interaction mechanism or scale up a practical technology for ash recycling. For example, an inappropriate experimental design in a study of ash-incorporated concrete may mislead readers, possibly due to the lack of background in concrete [41]. Thus, an interdisciplinary area that links MSWI ash, concrete, and environmental justice deserves attention, yet remains unexplored.

This paper aims to link existing work and trends in MSWI ash-incorporated cement and concrete and explore future paths to mitigate environmental injustice at scale. This study discusses potential strategies to guide and introduce engineers and scientists outside the construction sector to the MSWI ash waste management technologies. This paper also provides understandable background to the public. This work has great implications 
in promoting the use of MSWI ash in high-value standard-performance cement-based materials. This paper serves as a tutorial review for scientists and engineers new into the field of MSWI ash-incorporated cement/concrete, technical support for life-cycle assessment modelers and environmentalists, and a guide for decision-makers to mitigate environmental justice issues.

\section{Municipal Solid Waste Incineration Ash and Concrete}

\subsection{Municipal Solid Waste Incineration Ash}

For incinerating one metric ton of MSW in a waste-to-energy plant, 200-250 kg of MSWI bottom ash (BA) and 10-30 kg of MSWI fly ash (FA) are generated, respectively [21]. MSWI BA includes the residues that remain in waste-to-energy furnaces after incineration and the residues in air pollution control of the flue gas. MSWI FA is the fine porous particles separated by filters or electrostatic precipitators in air pollution control. The compositions of MSWI ash depend on many factors (e.g., MSW sources, metals separation technologies, and incineration facilities) [31]. Table 1 lists the chemical compositions of MSWI ash from different sources. Although an existing review concluded that compositions of MSWI ash from the same location are similar [42], discrepancies can be found in [43,44]. The chemical compositions of MSWI BA and FA from the same source are also significantly various, see Table 1. BA is oftentimes non-hazardous and contains $65-99 \mathrm{wt} . \%$ of minerals, glass, or ceramics, $7-16 \mathrm{wt} . \%$ of metals (e.g., zinc and aluminum), and 1-5 wt. $\%$ of unburnt organics [21]. The particle size of BA typically ranges from $0.1 \mathrm{~mm}$ to $10 \mathrm{~mm}$ with a small fraction of up to $30 \mathrm{~mm}$ [45]. BA is chemically heterogeneous, and the heterogeneity is particle size-dependent, see Table 2. From the same batch of MSWI, the $\mathrm{SiO}_{2}$ content of BA increases as the particle size increases. A similar trend is also found in [46], where HMs content follows an opposite trend with the particle size.

Table 1. Chemical compositions of MSWI bottom ash and fly ash from different sources (wt.\%).

\begin{tabular}{ccccccccccc}
\hline & $\mathbf{C a O}$ & $\mathbf{S i O}_{2}$ & $\mathbf{M g O}$ & $\mathbf{A l}_{\mathbf{2}} \mathbf{O}_{3}$ & $\mathbf{F e}_{2} \mathbf{O}_{3}$ & $\mathbf{P}_{\mathbf{2}} \mathbf{O}_{5}$ & $\mathbf{N a}_{2} \mathbf{O}$ & $\mathbf{K}_{\mathbf{2}} \mathbf{O}$ & $\mathbf{C l}$ & Ref. \\
\hline Fly ash & 16.4 & 27.2 & 2.5 & 11.7 & 1.8 & 0.3 & 5.9 & 5.8 & 7.2 & {$[47]$} \\
Fly ash & 47.4 & 2.2 & 1.6 & 1.0 & 0.8 & 0.7 & 4.9 & 6.7 & 25.0 & {$[48]$} \\
Fly ash & 45.4 & 13.6 & 3.2 & 0.9 & 3.8 & 1.7 & 4.2 & 3.9 & 9.7 & {$[49]$} \\
Bottom ash & 50.4 & 13.4 & 2.3 & 1.3 & 8.8 & 3.2 & 12.7 & 1.8 & 3.2 & {$[49]$} \\
Fly ash & 46.8 & 8.8 & 1.6 & 2.6 & 0.9 & 1.2 & 4.4 & 4.9 & N.P. & {$[50]$} \\
Bottom ash & 27.9 & 35.5 & 2.6 & 6.7 & 3.7 & 4.7 & 2.7 & 1.7 & N.P. & {$[50]$} \\
Fly ash & 46.3 & 8.4 & 2.7 & 1.8 & 1.3 & 0.7 & 6.2 & 5.2 & N.P. & {$[51]$} \\
Bottom ash & 25.9 & 42.1 & 3.7 & 8.6 & 5.7 & 3.8 & 3.9 & 1.9 & N.P. & {$[51]$} \\
Bottom ash & 49.8 & 10.8 & 2.4 & 5.7 & 9.6 & 3.2 & 1.7 & 10.7 & N.P. & {$[52]$} \\
Bottom ash & 32.3 & 32.9 & 2.3 & 12.2 & 6.0 & 3.1 & 2.2 & N.P. & 2.1 & {$[43]$} \\
\hline N.P. not reported. & & & & & & & & & &
\end{tabular}

Table 2. Chemical compositions of MSWI bottom ash with different particle sizes [43].

\begin{tabular}{|c|c|c|c|c|c|c|c|c|c|c|c|c|}
\hline \multirow{2}{*}{$\begin{array}{c}\text { Particle } \\
\text { Size }(\mu \mathrm{m})\end{array}$} & \multirow{2}{*}{$\begin{array}{c}\text { Weight } \\
\text { Fraction (\%) }\end{array}$} & \multicolumn{11}{|c|}{ Chemical Compositions (wt.\%) } \\
\hline & & $\mathrm{SiO}_{2}$ & $\mathrm{Al}_{2} \mathrm{O}_{3}$ & $\mathrm{Fe}_{2} \mathrm{O}_{3}$ & $\mathrm{CaO}$ & $\mathrm{TiO}_{2}$ & $\mathrm{P}_{2} \mathrm{O}_{5}$ & $\mathrm{MgO}$ & $\mathrm{Na}_{2} \mathrm{O}$ & $\mathrm{Cl}$ & L.O.I & Others \\
\hline$<0.425$ & 8.5 & 16.8 & 10.8 & 4.6 & 47.4 & 2.1 & 2.8 & 2.6 & 2.1 & 3.7 & 4.9 & 2.5 \\
\hline $0.425-0.85$ & 15.4 & 26.9 & 11.3 & 6.2 & 39.5 & 1.8 & 2.8 & 2.3 & 2.1 & 2.4 & 2.3 & 2.5 \\
\hline $0.85-2.00$ & 16.0 & 32.6 & 12.7 & 6.8 & 32.6 & 1.4 & 2.9 & 2.2 & 2.1 & 1.7 & 1.6 & 3.5 \\
\hline $2.00-4.75$ & 29.9 & 40.2 & 13.1 & 8.9 & 24.7 & 1.2 & 2.5 & 2.0 & 2.2 & 1.3 & 1.3 & 2.5 \\
\hline$>4.75$ & 30.3 & 48.9 & 11.5 & 5.2 & 17.6 & 0.8 & 2.1 & 1.7 & 3.0 & 0.4 & 0.3 & 8.6 \\
\hline Bulk & 100.0 & 32.9 & 12.2 & 6.0 & 32.3 & 1.5 & 3.1 & 2.3 & 2.2 & 2.1 & 3.8 & 1.6 \\
\hline
\end{tabular}

The typical particle size distribution of MSWI FA is 1-300 $\mu \mathrm{m}$ [42]. MSWI FA is typically more calcium- and/or alkali- rich than BA because lime or sodium carbonate is used in acid gas neutralization during air pollution control [53]. MSWI FA contains over 5\% of unburnt organics [54], and the upper bound is sometimes nearly 35\% [31]. MSWI FA is 
hazardous with the presence of HMs, sulfide, and chloride due to their vaporization during incineration, see Table 3 for the HMs content. During incineration, vaporized compounds adsorb on the large surface area of fine fly ash particles [55]. Note that the variability in HMs content of MSWI FA from different sources can be three orders of magnitude [38].

Table 3. The heavy metal content of MSWI bottom ash and fly ash.

\begin{tabular}{ccccccccc}
\hline & \multicolumn{7}{c}{ Heavy Metal Content $(\mathbf{m g} / \mathbf{k g})$} & \multirow{2}{*}{ Ref. } \\
\cline { 2 - 7 } & $\mathbf{Z n}$ & $\mathbf{B a}$ & $\mathbf{C u}$ & $\mathbf{P b}$ & $\mathbf{M n}$ & $\mathbf{N i}$ & $\mathbf{C r}$ & \\
\hline Bottom ash & 3016 & 3970 & 391 & 988 & 1360 & 139 & 634 & {$[44]$} \\
Bottom ash & 3193 & 1126 & 2321 & 687 & 620 & 105 & 393 & {$[56]$} \\
Bottom ash & 3800 & 1300 & 2700 & 1400 & 100 & 240 & 450 & {$[57]$} \\
Fly ash & 17,000 & 140 & 840 & 3000 & 1100 & 220 & 490 & {$[57]$} \\
Fly ash & 37,384 & N.P. & 3081 & 1356 & N.P. & 1584 & 566 & {$[58]$} \\
Fly ash & 3692 & N.P. & 2817 & 826 & N.P. & 78 & 1369 & {$[59]$} \\
\hline
\end{tabular}

\subsection{Concrete}

Concrete, the most common construction material, is made from $10-15 \%$ binder (typically PC), $15-20 \%$ tap water, and $65-75 \%$ aggregates (fine and coarse) by volume. Fine aggregate, sand, or crushed stone, has a particle size range of $150 \mu \mathrm{m}-4.75 \mathrm{~mm}$. The particle size range of coarse aggregate, gravel, is typically $4.75 \mathrm{~mm}-38 \mathrm{~mm}$. Figure 1 represents the structure of PC-based concrete at different scales. Ordinary Portland cement (OPC; $\mathrm{Ca}, \mathrm{Si}, \mathrm{Al}$, and Fe-rich pure $\mathrm{PC}$ ) reacts with water, forming hardened cement pastes that bind aggregates. The common water-to-binder ratio of concrete is $0.2-0.6$. Lower ratios correspond to fewer water-induced pores, thus higher strengths. Compressive strength is the most important property of concrete as a building material. Hydrated cement generates calcium hydroxide and calcium silicate hydrate (C-S-H, the primary binding phase) and yields a pore solution with a $\mathrm{pH}$ of $\sim 13$ [60]. This basic environment limits the corrosion of steel rebar [61], which is important as concrete in buildings is commonly steel-reinforced. Supplementary cementitious materials (SCMs), typically industrial byproducts, are used to partially replace OPC to lower the carbon footprint and cost of concrete and improve concrete's long-term mechanical properties and durability [62,63]. Figure 2 shows the approximate compositions of PC, MSWI ash, and industrial byproducts (coal fly ash, silica fume, and ground granulated blast-furnace slag (GGBFS)).

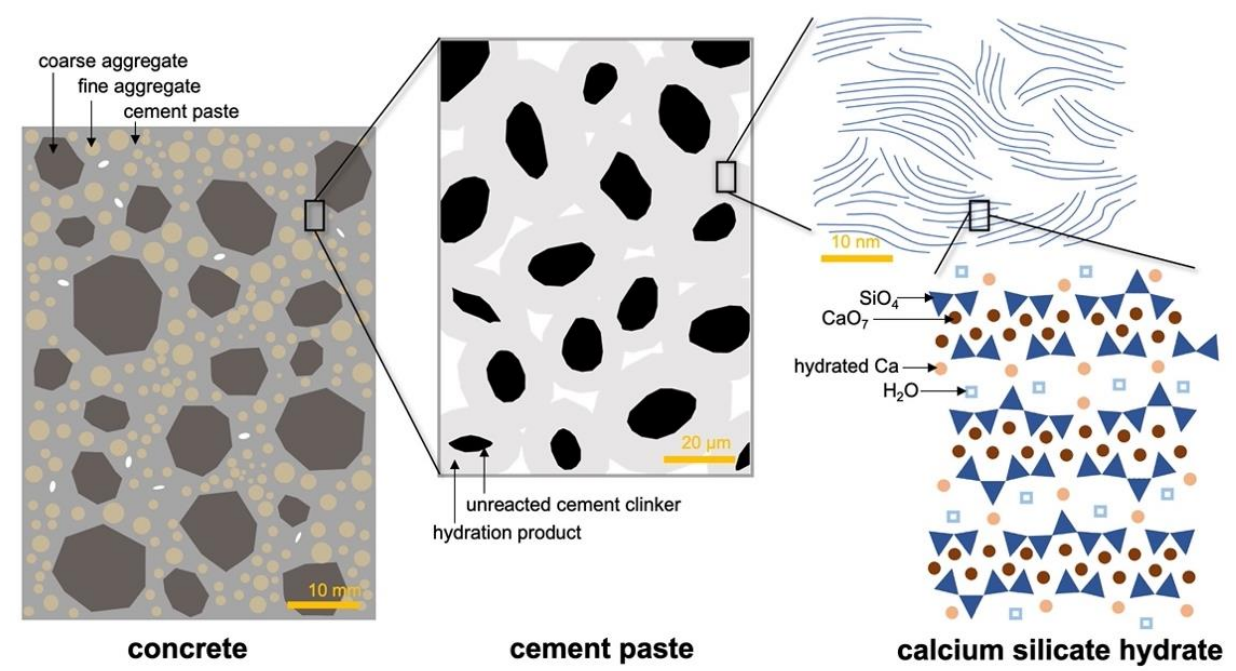

Figure 1. Schematic diagrams of concrete at different scales (derived from $[61,64-66]$ ). C-S-H is mesoporous with high surface areas. Hydrated Ca of C-S-H can be substituted by HMs, and the layered nanostructure adsorbs many organics and ions. 


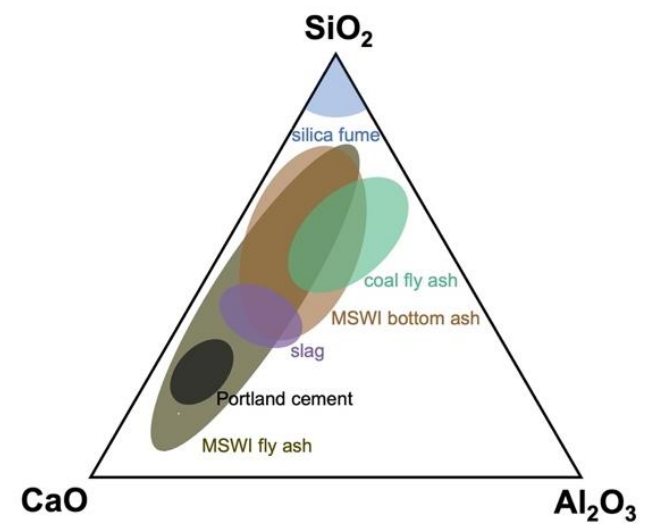

Figure 2. Approximate compositions of Portland cement, MSWI ash, and common industrial byproducts as cement substitutes (coal fly ash, silica fume, and ground granulated blast-furnace slag (GGBFS)). Coal fly ash, silica fume, and GGBFS are byproducts from coal-fired power plants, silicon/ferrosilicon manufacture, and crude iron production, respectively.

C-S-H is a layered phase with a grain size of $3-5 \mathrm{~nm}[67,68]$. C-S-H can adsorb many organics due to its high surface area [69,70] and immobilize many toxic elements (e.g., Cr, $\mathrm{Pb}, \mathrm{Sb}$, and $\mathrm{Zn}$ ) by interlayer Ca substitution and surface complexation [71-73]. Minor hydration products, e.g., ettringite $\left(\mathrm{Ca}_{6} \mathrm{Al}_{2}\left(\mathrm{SO}_{4}\right)_{3}(\mathrm{OH})_{12} \cdot 26 \mathrm{H}_{2} \mathrm{O}\right)$, can also immobilize toxic elements [74]. PC hydration products can also bind chlorides [75]. $\mathrm{Cl}$ in its inorganic form is non-toxic, but it destabilizes the passive film of steel rebar in reinforced concrete, resulting in rebar corrosion [61].

Many other types of cement also yield ettringite or other hydration products that immobilize toxic elements. However, alternative cement (e.g., magnesium phosphate cement [76-78] and calcium aluminate cement [79-81]) is expensive and has pitfalls in practical applications (e.g., service temperature, setting time, and flowability). Non-PCbased alternative cement is merely a niche product with a market size incomparable to the volume of MSWI ash and PC.

As mentioned earlier, the environmental impacts (e.g., $\mathrm{CO}_{2}$ emission and air pollutants) of concrete are significant due to its massive production [82]. The production of cement and concrete also causes environmental justice issues [26]. The replacement of concrete raw materials, e.g., cement and aggregates, with MSWI ash can be a potential pathway to mitigate the environmental justice issues in both fields. The efficiency of this incorporation depends on the characteristics of MSWI ash and the properties of cement and concrete.

\subsection{MSWI Ash Incorporation in Concrete?}

Although PC and MSWI ash share similar chemical compositions (Figure 2), high content of $\mathrm{Ca}, \mathrm{Si}, \mathrm{Al}$, and $\mathrm{Fe}[83,84]$, a limited volume of raw MSWI ash can be used as cement substitutes [85] or the raw materials in cement/concrete production [86]. The incorporation of the coarse fraction of raw MSWI BA in concrete as aggregates is limited by the presence of metallic aluminum, which reacts with the basic environment of concrete, generating hydrogen gas [87]. $\mathrm{H}_{2}$ gas induces the expansion and cracking of hardened cement pastes or low-density and low-strength products [88]. The incorporation of fine raw FA in concrete is limited by its high content of chlorides, sulfate, organic matters, and $\mathrm{HMs}$, e.g., $\mathrm{Zn}, \mathrm{Cu}, \mathrm{Cr}, \mathrm{Hg}$, and $\mathrm{Pb}$. Soluble chlorides in reinforced concrete cause steel-rebar corrosion and concrete cracking [89]. Excessive sulfates delay cement setting and concrete hardening $[90,91]$. The highly porous microstructure of FA causes higher water demands of ash-incorporated cement pastes, thus lowering concrete strength. Consequently, pretreatment is required to produce MSWI ash-incorporated cement-based materials with standard performance. 
The leaching of HMs and organic matters from MSWI ash, particularly FA, is hazardous, thus, a contributor to environmental justice. The misuse of MSWI ash in concrete or mishandling near waste-to-energy plants may lead to secondary environmental justice issues. Thus, leaching tests must be conducted to evaluate the ecotoxicity of MSWI ash. The concentrations of toxic elements and compounds of leachates after cement/concrete immobilization must comply with regulatory limits.

\section{Leaching from MSWI Ash}

The leaching behaviors of MSWI ash are complex and controlled by many factors, e.g., $\mathrm{pH}$, liquid-to-solid ratios, and ash characteristics [92]. The leaching rate of many $\mathrm{HMs}$ is sensitive to $\mathrm{pH}$. Leachates of raw MSWI ash are typically basic due to the high $\mathrm{CaO}, \mathrm{Na}_{2} \mathrm{O}$, and $\mathrm{K}_{2} \mathrm{O}$ content of raw ash. The solubility of most $\mathrm{HM}$ species (e.g., $\mathrm{Cu}$, $\mathrm{Zn}, \mathrm{Cd}$, and $\mathrm{Pb}$ ) decreases with increasing solution $\mathrm{pH}$ [53], and $\mathrm{Al}$ solubility reaches the maximum under both acidic and basic conditions. The maximum leaching capacity of As, $\mathrm{Se}$, and $\mathrm{Ba}$ plateaus at $\mathrm{pH}>11$ [93]. However, a study reported that $\mathrm{Zn}$ leaching is less $\mathrm{pH}$-dependent [42]. The solubility of $\mathrm{Na}, \mathrm{K}, \mathrm{Cl}$, and $\mathrm{S}$ is less $\mathrm{pH}$-dependent [53], and their leaching behavior is less critical because (1) these elements are not toxic, and (2) they can be adsorbed by cementitious materials (which will be discussed later). The influence of $\mathrm{pH}$ on MSWI ash leaching is not critical in concrete studies because the $\mathrm{pH}$ of PC-based matrix is typically $\sim 13$ [60]. Even after years of aging (i.e., carbonation by atmospheric $\mathrm{CO}_{2}$ ), the pore solution of cement-based materials is still basic [94]. The leaching limits of selected HMs for landfilling solid waste are listed in Table 4.

Table 4. Leaching limits of selected HMs for the acceptance of solid waste at landfills in different countries (mg/L). (updated from [45]).

\begin{tabular}{cccccccccc}
\hline & Code & Zn & Ba & $\mathbf{C u}$ & $\mathbf{P b}$ & $\mathbf{M n}$ & $\mathbf{N i}$ & $\mathbf{C r}$ & $\mathbf{H g}$ \\
\hline United States & CFD40 216.3 & 70 & 7.6 & - & 0.15 & - & 1 & 5 & 0.009 \\
China & GB18598-2019 & 1 & 1 & 0.5 & 0.05 & - & 0.05 & 0.1 & 0.001 \\
Germany & EN12457-2 & 3 & - & 3 & 0.5 & - & 0.4 & 2 & 0.002 \\
Netherlands & Column & 2.3 & 6 & 0.32 & 0.97 & - & 0.7 & 0.35 & 0.017 \\
United Kingdoms & 2003/33/EC & 4 & 20 & 2 & 0.5 & - & 0.4 & 0.5 & 0.01 \\
\hline
\end{tabular}

The characteristics of the ash (i.e., grain size, surface area, and composition) all affect the leaching behaviors. Generally, a finer grain size, higher surface area, and higher element content of the ash, and a higher liquid to ash ratio result in faster leaching [95], which agrees with the principles of mineral and glass dissolution [96-98]. However, the concentration of $\mathrm{Cu}, \mathrm{Ba}$, and $\mathrm{Mn}$ is controlled by the ion leaching capacity and the competition among ions [42]. HMs concentrations of leachates from MSWI BA are lower than MSWI FA due to the lower HMs content and the denser structure of BA. The leaching behaviors of MSWI ash are complex when ash is incorporated into cementitious materials. The influence of liquid-to-solid ratios on leaching is less important because the typical water-to-binder ratio of cementitious materials is 0.2-0.6 [61].

Another important source of toxicity from MSWI ash is organic matters, including unburnt organics from MSW or byproducts after incineration. These organic matters take up to $5 \mathrm{wt} . \%$ of total MSWI ash. The organic leachates consist of dissolved organic matters (DOMs) and xenobiotic organic compounds. Many leached DOMs, such as humic acid, fulvic acid, and volatile fatty acids $[99,100]$ are not considered highly toxic. The presence of one of the DOMs may significantly affect the bulk leachate compositions due to the complex organic reactions among the DOMs [101]. Xenobiotic organic compounds, such as dioxin and furan [102,103], are known for high toxicity. The leaching of organic matters from MSWI ash induces the leaching of the inorganics in the ash [104].

Organic matters, HMs, and many other elements (e.g., As and $\mathrm{Sb}$ ) are toxic sources from MSWI ash and contributors to environmental injustice. Lowering the concentrations by incorporating MSWI ash into cement/concrete is essential to alleviating the construction- 
and waste management-induced environmental injustice. Pretreatment of MSWI ash can lower the hazard level of MSWI ash and facilitate its incorporation into cementitious materials. Thus, the pretreatment of MSWI ash is one of the preconditions of MSWI ash-concrete-related environmental justice.

\section{Pretreatment of MSWI}

\subsection{Industrial Scale Pretreatment}

Many pretreatment methods have been applied to lower the content of chlorides, HMs, and/or organic matters of MSWI ash. The industrial pretreatment methods include water-washing, aging, magnetic separation, mechanical separations, and eddy current separation [105]. The separation methods reclaim ferrous and non-ferrous metals (including precious metals, aluminum, and HMs). These industrial-scale separation technologies are mature and very commonly used. Thus, this paper does not cover these separation technologies.

\subsubsection{Water-Washing}

Water-washing is the most common industrial method to remove soluble salts (e.g., $\mathrm{NaCl}, \mathrm{KCl}$, or $\mathrm{CaCl}_{2}$ ) from MSWI ash, particularly FA. This pretreatment is cost-efficient to remove chlorides, which trigger the corrosion of steel rebar and concrete mixers. However, water-washing typically can only lower the chloride content down to $\sim 0.5 \mathrm{wt} . \%$ due to the presence of low-solubility chlorides [106]. Calcium oxychloride $(\mathrm{CaOCl})$ is challenging to remove by only one time of washing. Mao et al. found that the influence of waterto-solid ratios on chloride removal was less pronounced when the ratio was over three, and the replication of washing at this ratio was more efficient and water-saving than at a ratio of 20 [107]. $\mathrm{CaOCl}$ can be partially removed with this additional water-washing. Further chloride removal by over $99 \%$ required saturated lime water to unbalance the chemical equilibrium. This washing condition removed $\sim 30 \mathrm{wt} . \%$ of the total soluble solid of MSWI FA [108]. Because water-washing is essentially a leaching process at high waterto-solid ratios, it yields leachates with HMs, reducing the HMs content of washed MSWI ash [109]. The drying of such leachate generates filtration cakes, a mixture of HMs, salts, and other phases. The utilization of hazardous filtration cakes is challenging and has rarely been explored. The filtration cakes must be handled and stored cautiously. Otherwise, their leakage-induced soil or groundwater contamination could be a secondary source of environmental injustice. Further studies on the utilization and storage of filtration cakes from MSWI ash pretreatment are needed.

\subsubsection{Aging}

Aging is a series of processes of oxidation, hydration, and carbonation, which efficiently lower the leaching of HMs. The aging products, mainly inorganic phases from hydration and carbonation, e.g., ettringite, $\mathrm{C}-\mathrm{S}-\mathrm{H}$, and calcium carbonates $\left(\mathrm{CaCO}_{3}\right)$, can bind HMs, reducing potential leaching [110]. Aging causes the consumption of metallic $\mathrm{Al}$ pieces in an alkaline environment, forming colloidal aluminum hydroxide, which immobilizes HMs [111].

\subsection{Lab-or Pilot-Scale Pretreatment}

\subsubsection{Thermal Pretreatments}

Thermal pretreatment is a series of simple methods to reduce HMs, toxic organic matters (e.g., dioxin and furan), and chlorides of MSWI FA and densifies the porous structure. Thermal pretreatments of MSWI ash include three processes, sintering, melting, and vitrification.

Sintering, typically at $600-1200{ }^{\circ} \mathrm{C}$ (below melting points of the major ash components), coalesces and densifies porous FA grains [112]. The high-temperature condition decomposes most organic matters (e.g., humic acid, fulvic acid, volatile fatty acids, dioxin, and furan). After sintering, the product is denser with lower porosity compared to raw ash. 
The decreased porosity limits the leaching HMs, and any remained organic matters. Chlorine and $\mathrm{HMs}$, such as $\mathrm{Pb}$ and $\mathrm{Hg}$, vaporize during sintering. $\mathrm{Cl}$ facilitates the vaporization of $\mathrm{HMs}$, e.g., in the form of $\mathrm{PbCl}_{2}, \mathrm{CuCl}_{3}$, or $\mathrm{ZnCl}_{2}$ [112], under high-temperature conditions. Higher sintering temperature favors the removal of chloride [113]. Thus, the $\mathrm{Cl}$ and HMs content of sintered ash is significantly declined. Note that incomplete vaporization of $\mathrm{Cr}$ during the heat treatment may lead to the oxidation of $\mathrm{Cr}(\mathrm{III})$ to $\mathrm{Cr}(\mathrm{VI})$ [114]. Compared to $\mathrm{Cr}(\mathrm{III}), \mathrm{Cr}(\mathrm{VI})$ is more soluble, thus, more leachable. Sintering of MSWI FA is essentially a process of recrystallization, solid-state reactions, and phase transition. Thus, the sintered product has lower amorphous content compared to raw ash. Sintered products are suitable as aggregates due to their high density and low reactivity [115].

Melting MSWI FA residues at up to $1400{ }^{\circ} \mathrm{C}$, followed by water-quenching, produces a slag, which is nearly fully amorphous [116]. Similar to sintering, chlorine, sulfur, and HMs vaporize during the melting process, and organics matters decompose [117]. The final product has higher $\mathrm{CaO}, \mathrm{Al}_{2} \mathrm{O}_{3}$, and $\mathrm{SiO}_{2}$ content. The volatility of $\mathrm{HMs}$ of $\mathrm{BA}$ follows the order: $\mathrm{Cu}>\mathrm{W}>\mathrm{Pb}>\mathrm{Zn}>\mathrm{Sr}>\mathrm{Mo}>\mathrm{Cr}>\mathrm{Ni}$, while other elements (e.g., $\mathrm{Cs}$ and Ba) showed limited volatility at $1100{ }^{\circ} \mathrm{C}$ [118]. A higher treatment temperature or longer melting time favors the formation of homogenous slag. The leachability (e.g., $\mathrm{Cd}, \mathrm{Cr}$, $\mathrm{Pb}$, and $\mathrm{Zn}$ ) of the slag is significantly lower compared to raw ash due to the minimized porosity and reduced $\mathrm{Cl}$ and $\mathrm{HMs}$ (e.g., $\mathrm{Pb}$ and $\mathrm{Cd}$ ) content of melted products [119]. The MSWI ash slag with high amorphous content can be upcycled as a cement substitute or a precursor of alkali-activated materials [120].

Vitrification is a process to melt the MSWI FA residue with the addition of other solid wastes or additives (also known as flux agents). The addition of basic oxides (e.g., $\mathrm{Na}_{2} \mathrm{O}, \mathrm{K}_{2} \mathrm{O}, \mathrm{MgO}$, and $\mathrm{CaO}$ ) or solid wastes with high content of basic oxides lowers the melting point of the ash residue [121,122], thus reducing the energy consumption of thermal pretreatment. Although flux agents lower the cost of fuel consumption, the trade-off of melting temperature and cost of flux agents must be considered (e.g., $\mathrm{B}_{2} \mathrm{O}_{3}$ is relatively expensive). Flux agents can limit the vaporization of certain $\mathrm{HMs}$, e.g., $\mathrm{Pb}$, $\mathrm{Cd}$, and $\mathrm{Zn}$, with the addition of $\mathrm{B}_{2} \mathrm{O}_{3}$ [123]. Similar to melting, vitrification lowers the leachability of certain HMs of MSWI FA, increases the product density, and vitrifies the ash residue [124]. The vitrificated product is also potentially a cement substitute or a precursor of alkali-activated materials (will be discussed later).

Although vaporization of HMs potentially lowers the HMs content of processed ash, the vapor from thermal treatment must be appropriately managed. MSWI FA should be water-washed to remove $\mathrm{Cl}$ before thermal treatment if vapors are not treated. The mismanagement of toxic vapors would be an enabler of environmental injustice. The treatment of HMs vapor benefits precious metal recovery, thus potentially lowering the pretreatment cost.

\subsubsection{Hydrothermal Pretreatment}

Hydrothermal pretreatment is a cost-efficient method to decompose organic matters, immobilize HMs, and solidify ash residues. The processing temperature typically ranges from $150{ }^{\circ} \mathrm{C}$ to $300^{\circ} \mathrm{C}$. Thus, the energy consumption of hydrothermal pretreatment is relatively low. The decomposition of organic matters in MSWI ash is temperature-sensitive. For example, dioxin and furan in MSWI FA completely decomposed after $20 \mathrm{~min}$ of hydrothermal pretreatment at $300{ }^{\circ} \mathrm{C}$ due to dechlorination reaction [125]. During the hydrothermal reaction, aluminosilicate minerals, e.g., zeolite and tobermorite, formed at the expense of $\mathrm{Al}$ and $\mathrm{Si}$ from ash under alkaline conditions [126]. These minerals have large surface areas and reactive atomic configuration to immobilize HMs [127]. The efficiency of HMs immobilization is relevant to reaction age and the addition of additives (e.g., slaked lime). For example, Zn concentration of leachate declined by two orders of magnitude after $6 \mathrm{~h}$ of hydrothermal pretreatment due to the formation of C-S-H, while $\mathrm{Cr}$ concentration decreased by only $40 \%$ after $72 \mathrm{~h}$ of curing at $200{ }^{\circ} \mathrm{C}$ [128]. A further $40 \%$ reduction in $\mathrm{Cr}$ concentration was observed with the addition of $10 \mathrm{wt} . \%$ slaked 
lime, while the slaked lime addition did not promote the immobilization of $\mathrm{Zn}$ and $\mathrm{Pb}$. A recent hydrothermal pretreatment study suggested that $\mathrm{Na}_{2} \mathrm{HPO}_{4}$ additive promoted the solidification of $\mathrm{HMs}$ of ash compared to $\mathrm{NaOH}$ additive [129]. However, phosphates may be expensive for large-scale applications, especially in concrete-related production. The autoclaved lime-MSWI BA pastes in [128] with flexural strengths over $25 \mathrm{MPa}$, and immobilized HMs can be directly used as construction materials.

\subsubsection{Wet Grinding}

MSWI BA with particle sizes of $0.1-10 \mathrm{~mm}$ is oversized as a cement substitute (average diameter $<50 \mu \mathrm{m}$ ), thus griding is required for breaking down BA particles. Under wetgrinding conditions, inherent $\mathrm{Ca}$ and alkali provide a basic environment for the dissolution of metallic $\mathrm{Al}$ in MSWI ash [130]. The reaction products, e.g., C-S-H and colloidal aluminum hydroxide, along with the alkaline solution, immobilize $\mathrm{HMs}$, e.g., $\mathrm{Cr}, \mathrm{Pb}$, and $\mathrm{Zn}$, of MSWI FA [131,132].

\subsubsection{Accelerated Carbonation}

Natural carbonation of MSWI ash by atmospheric $\mathrm{CO}_{2}$ is slow. MSWI ash carbonation can be accelerated by concentrated $\mathrm{CO}_{2}$ from different sources. This process is similar to the aforementioned natural weathering but much faster. A recent study showed that $\mathrm{Pb}$ concentration from MSWI FA leachates decreased by $92 \%$ with oxy-fuel combustion flue gas, $95 \%$ with pure $\mathrm{CO}_{2}$, and $84 \%$ with air combustion flue gas. After carbonation by oxy-fuel combustion, flue gas, $\mathrm{Zn}, \mathrm{Cu}$, and $\mathrm{Cr}$ concentration decreased by $69 \%, 25 \%$, and $11 \%$, respectively [133]. Cornelis et al. found that $\mathrm{Sb}$ leachability from BA depends on $\mathrm{pH}$ (i.e., ash compositions and carbonation degree) [134]. Carbonation-induced $\mathrm{pH}$ drop triggered $\mathrm{Sb}$ leaching, and $\mathrm{Sb}$ concentration after full carbonation exceeded the regulatory limit. The influences of accelerated carbonation on leachability depend on the nature of raw MSWI FA. Sulfate, chloride, and Pb leachability of four different sources of MSWI FA decreased after accelerated carbonation [135]. In contrast, the influences of carbonation on $\mathrm{Cd}$ and $\mathrm{Zn}$ leachability are scattered among different sources of FA.

Concentrated $\mathrm{CO}_{2}$ is precious and in a shortage in the concrete industry. Concentrated $\mathrm{CO}_{2}$ is the key raw material of many types of alternative cement (e.g., carbonated $\mathrm{MgO}$ cement [136-138], $\mathrm{CaCO}_{3}$-based cement [139,140], carbonated wollastonite [141], and carbonated magnesium silicate [142]). The hardening and strength development of the carbonation-based cement systems rely on the uptake of concentrated $\mathrm{CO}_{2}$. The competition in concentrated $\mathrm{CO}_{2}$ demands between MSWI ash carbonation and other cement deserves further attention in resources management. The carbonation of MSWI ash may take advantage of $\mathrm{CO}_{2}$-rich flue gas from waste-to-energy plants.

\section{Use of MSWI Ash in Concrete}

\subsection{Use in OPC Production}

The high content of $\mathrm{Al}, \mathrm{Si}, \mathrm{Ca}$, and $\mathrm{Fe}$ in MSWI ash makes it a potential raw material for producing OPC clinker (the major component of OPC without gypsum). The cocombustion of MSWI ash and typical OPC raw materials (i.e., mainly limestone and clay) is a cost-effective decarbonization strategy in the circular economy. Blending Ca-rich MSWI ash into the PC feedstock lowers the fraction of limestone, the decomposition of which emits $\mathrm{CO}_{2}[142,143]$. The co-combustion at $1450{ }^{\circ} \mathrm{C}$ also decomposes unburnt organic matters and saves the energy for pretreatment. The direct use of raw MSWI ash in the PC feedstock is widely limited by the presence of chlorides and alkalis in raw MSWI ash. The presence of Cl-rich raw MSWI ash, particularly FA, in cement kilns can cause blockages and corrosion of kilns [144]. Cl content in PC is also restricted by standards (e.g., ACI and ASTM) for the risk of rebar corrosion [145]. Excessive alkalis would cause a porous microstructure of cement matrix, slump loss, and poor strength gain due to the presence of orthorhombic tricalcium aluminate in PC [61,91]. Excessive alkalis in OPC may also lead to a detrimental alkali-silica reaction, which causes cracking around reactive siliceous 
aggregates [146]. Only $0.3 \%$ of raw MSWI FA can be utilized due to its nonideal chemical compositions [31]. Despite the low utilization ratio of raw MSWI FA, the total potential of raw MSWI ash utilization in clinker manufacturing is still remarkable considering the massive production of OPC clinker ( $3 \mathrm{Gt} /$ year) [23]. HMs concentration is not considered an issue in ash-clinker co-combustion because the HMs content has been significantly diluted. Higher fractions of raw MSWI BA may be added into PC feedstock due to its lower content of chlorides and alkalis compared to raw MSWI FA.

MSWI ash must be pre-treated to remove chlorine and alkalis for boosting the fraction of MSWI ash in PC raw materials. Water-washing can efficiently lower the chlorine and alkalis content and promote the co-combustion of MSWI ash with other PC raw materials. Thermal pretreatment of MSWI ash is also efficient in removing chlorine and alkalis, but the method is energy-intensive and redundant in terms of the thermal decomposition of organics. After water-washing, Pan et al. synthesized OPC with 1.75\% MSWI FA or 3.5\% BA in the raw materials [49]. The products conformed to standards except for a slightly longer setting time, possibly due to extended sintering of the clinker.

\subsection{Use in Special Cement Manufacture}

The use of raw MSWI ash in the feedstock in the industrial-scale production of other types of cement (e.g., calcium sulfoaluminate cement-based) may also be impractical due to the $\mathrm{Cl}$-induced kiln and rebar corrosion. Unfortunately, existing lab-scale studies have ignored the detrimental effects of $\mathrm{Cl}$ [35]. Calcium sulfoaluminate cement clinker can not bind $\mathrm{Cl}$ in kilns because the clinker phases accommodate little $\mathrm{Cl}$. Alternatively, an exhaust gas bypass can be installed to vent the alkali- and chloride-laden vapor to avoid the issue during kilning operation [147]. Note that the payback of any upgrade to a cement plant costs at least 1-3 years [148]. After water-washing, Cl-removed MSWI FA can be successfully used as a raw material of calcium sulfoaluminate cement [149]. Mao et al. synthesized calcium sulfoaluminate cement from raw materials with $35 \%$ of washed MSWI FA [107]. The leaching concentrations of HMs from the cement-based products met regulatory limits.

Chloroellestadite $\left(\mathrm{Ca}_{5}\left(\mathrm{SiO}_{4}\right)_{1.5}\left(\mathrm{SO}_{4}\right)_{1.5} \mathrm{Cl}\right)$-rich clinker (e.g., eco-cement in [150] and alinite cement [151]) can bind $\mathrm{Cl}$ from raw MSWI ash. Guo et al. synthesized alinite cement from raw materials with $30 \mathrm{wt} . \%$ of MSWI fly ash [152]. This MSWI FA utilization ratio is much higher than that for OPC production, $\sim 0.3 \%$. The $\mathrm{HMs}$ (e.g., $\mathrm{Pb}$ and $\mathrm{Hg}$ ) concentration of leachate of hydrated chloroellestadite-rich cement is lower than regulatory limits $[151,153]$. Moreover, the sintering temperature of chloroellestadite-rich clinker is only $\sim 1100{ }^{\circ} \mathrm{C}$. Thus, the production of chloroellestadite-rich cement is considered as an efficient solution to recycling MSWI ash.

The mechanical properties of alternative cement-based products are comparable to those of PC-based. Nevertheless, alternative cement may be only used in a niche market (e.g., in specific scenarios with nonmetallic kiln and for non-reinforced concrete production).

\subsection{Use as Cement Substitutes (Supplementary Cementitious Materials)}

SCMs are (alumino)siliceous or calcium aluminosiliceous materials and calcium carbonate used as partial substitutes for OPC or clinker [154]. The reaction mechanisms of SCMs in hydrated cement are as follows: (1) pozzolanic reaction: calcium hydroxide in hydrated PC reacts with amorphous (alumino)silica (e.g., low-Ca coal fly ash), forming calcium (alumino)silicate hydrate (C-(A-)S-H), also a binding phase [155]; (2) cementitious reaction: amorphous calcium aluminosilicate (e.g., GGBFS and high-Ca coal fly ash) reacts with water, also forming C-A-S-H; (3) dilute and filler effects: for example, limestone powder (mainly $\mathrm{CaCO}_{3}$ ) provides $\mathrm{Ca}$ as a template for C-S-H nucleation and growth and accelerates PC hydration [156]. Note that not all amorphous silicates are potential SCMs. For example, amorphous calcium iron silicate in copper slag is hardly reactive in PC systems due to its high iron content [157]. SCMs are either pre-blended with OPC clinker 
during the production of blended PC or added into concrete mixers with OPC during the production of concrete.

It is worth mentioning that the supply of industrial byproduct SCMs (mainly coal fly ash) is declining due to the current trend in the retirement of coal-fired power plants [158]. With the growing cement demand (6 Gt/year by 2050 [22]), the shortage of industrial byproduct SCM would exacerbate. After appropriate treatments, MSWI ash, as a pozzolanic material, can potentially lessen the global shortage of SCMs. MSWI ash must be appropriately managed as SCMs in academic studies and practical applications. For example, MSWI ash must not be used to replace low-grade PC (e.g., 32.5-grade in [159]), which has pre-blended with a large fraction of SCMs. The partial replacement of such low-grade PC with additional SCMs would cause low cement hydraulic reactivity and competition between pozzolanic SCMs. The mechanical properties of such ill-designed cement-based products are poor. Thus, such MSWI ash incorporated cement-based materials are more considered as products of the stabilization/solidification (S/S) process. These low-value products are more suitable as landfills with low toxic leachability or construction materials in niche markets [160]. The low/zero-value cement-based S/S landfill may not essentially benefit environmental justice, particularly when the $S / S$ process significantly increases the total landfill volume.

Many factors limit the use of raw MSWI ash as SCMs. The moisture in stocked ash increases the water-to-binder ratio in blended-PC systems, thus lowering the mechanical properties of final products. The high S content of raw MSWI ash retards cement hydration, particularly the dissolution of tricalcium aluminate $[90,161]$, thus delaying cement setting, while $\mathrm{Cl}$ in ash accelerates cement hydration [162]. Thus, the influences of unwashed ash on cement settings are complex; prolonged [47] and shortened setting time [163] of raw ash-containing pastes have been reported. In addition, soluble $\mathrm{Cl}$ triggers steel-rebar corrosion. The metallic $\mathrm{Al}$ and $\mathrm{Zn}$ in raw ash pose the expansion and cracking of lowstrength ash-containing pastes [37]. The low amorphous content and large grain size of BA may limit its reactivity in PC systems. Thus, raw ash contributes little to strength development. Even with the addition of alkaline activators (e.g., $\mathrm{CaSO}_{4}$ and $\mathrm{Na}_{2} \mathrm{SO}_{4}$ ), the compressive strength of hybrid cement with $40 \%$ MSWI mix ash is still $\sim 40 \%$ lower than OPC [164]. The low strength of blended cement incorporated with raw MSWI ash limits its wide use as standard-performance construction materials despite its HMs immobilization advantage. These low-strength blended cement-based materials from the $S / S$ process are niche products [160]. Thus, pretreatment of MSWI ash is suggested for its appropriate utilization as SCMs.

The possible use of treated MSWI BA as SCMs depends on many factors, e.g., amorphous content, particle size, and compositions of PC and treated BA. Raw BA particle sizes are oversized; thus, milling and sieving are common processes. Juric et al. partially replaced OPC with milled BA, and the compressive strengths at 3-28 days were comparable to the $42.5 \mathrm{R}$ OPC group when the cement substitution was $<20 \mathrm{wt} . \%$. A $10 \%$ compressive strength reduction was observed at a substitution level of $30 \%$ at $28 \mathrm{~d}$. The leachability of the BA incorporated group met regulatory limits [165]. Similarly, Zhang and Zhao replaced $30 \mathrm{wt} . \%$ 42.5R OPC with wet-milled BA, while the blended group only exhibited similar or lower strengths compared to the pure OPC counterpart from 1 to 90 days [166]. Bertolini et al. compared the influences of wet- and dry-millings of BA on the mechanical properties of concrete [130]. Concrete containing cement substituted with $30 \mathrm{wt} . \%$ wet-milled BA exhibited similar or higher compressive strengths compared to 52.5R OPC concrete from 1 day to 180 days, while concrete containing $30 \mathrm{wt} . \%$ dry-milled BA substitution exhibited $55 \%$ lower strengths. The strength difference may be explained by the finer grains of wet-milled BA compared to dry-milled BA and the consumption of metallic $\mathrm{Al}$ and $\mathrm{Zn}$. Unfortunately, the lack of comprehensive characterization of treated BA limits the further understanding of pretreatment influences on the compositions and reactivity of BA. Joseph et al. established a pretreatment method that consumed metallic $\mathrm{Al}$ by the inherent alkalis in BA, and fine fractions of treated BA were used as the substitutes for 52.5N OPC [37]. The 
$28 \mathrm{~d}$ compressive strength of mortar with $52.5 \mathrm{~N}$ OPC substituted by $25 \mathrm{wt}$.\% treated BA was higher than $32.5 \mathrm{~N}$ coal fly ash-containing PC mortar and was over $75 \%$ of the strength of pure $52.5 \mathrm{~N}$ OPC mortar. The $90 \mathrm{~d}$ strength of BA-containing mortar was only $5 \%$ lower than $52.5 \mathrm{~N}$ OPC mortar. The study suggested that treated fine BA had higher pozzolanic reactivity than coal fly ash and was potentially an effective SCM. The treated BA delayed cement setting by $90 \mathrm{~min}$, but this extension was acceptable for practical applications. In summary, the mechanical performance of BA-containing cement-based materials depends on the reactivity of both PC and treated BA.

MSWI FA with particle sizes of 1-300 $\mu \mathrm{m}$ may be used as SCMs after washing-off toxic components and sieving. The reactivity of washed FA also depends on the compositions of raw ash. Washing may reduce the pozzolanic activity of FA despite the removal of chlorides, sulfates, and HMs [167]. On the contrary, Keppert et al. found that water-washed MSWI FA exhibited higher reactivity in 42.5R OPC concrete compared to unwashed counterpart [168]. Mortar containing FA water-washed at a water-to-solid ratio of 10 exhibited higher $28 \mathrm{~d}$ compressive strengths than those containing unwashed FA or FA washed at a water-tosolid ratio of 5 at the same cement replacement level. Among different washing conditions (water-to-solid ratio and solutions (water, $\left(\mathrm{NH}_{4}\right)_{3} \mathrm{PO}_{4}$, and $\mathrm{HCl}$ )), only mortar containing $10 \%$ FA water-washed at a water-to-solid ratio of 10 exhibited a $5 \%$ higher $28 \mathrm{~d}$ compressive strength compared to an OPC reference. The incorporation of unwashed or other washed FA in mortars diminished compressive strengths [168]. Higher cement replacement levels, e.g., $30 \mathrm{wt}$ \%, also resulted in lower strengths, which agreed with Bertolini et al. [130]. The environmental impacts (e.g., long-term leachability of toxic components) of washed FA-containing concrete deserve further attention in assessments.

Ground slag from melting MSWI FA has been successfully blended in PC as SCMs due to its high amorphous content (>95 wt.\%) of calcium aluminosilicate. Lin found that $20 \mathrm{wt} . \%$ of Type I, II, and belite OPC can be replaced with MSWI FA slag without compromising strengths at late ages (after 28 days) [120] due to the pozzolanic reaction [117,119]. Higher replacement levels delayed the setting of blended cement by $\sim 30 \mathrm{~min} \mathrm{[120].} \mathrm{The} \mathrm{PC}$ substitution lowered the early strengths by $\sim 10 \%$, e.g., at $1-28$ days $[120,169]$. The influences of MSWI FA slag on cement setting also depends on MSWI sources-another batch of slag

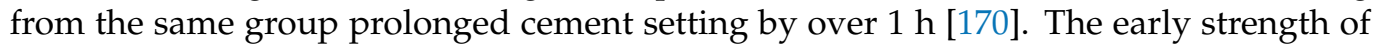
MSWI FA slag blended cement mortar can be improved by modifying slag reactivity. The $28 \mathrm{~d}$ strength of mortar containing $20 \%$ slag was comparable to the OPC group by adjusting the basicity with the addition of $\mathrm{CaCO}_{3}$ in the melting process [169]. The HMs (e.g., $\mathrm{Zn}$ $\mathrm{Cr}, \mathrm{Cu}$, and $\mathrm{Pb}$ ) concentration of leachates from the modified slag was significantly lower than the unmodified slag. Similarly, the reactivity of MSWI FA slag can be improved by comelting with MSWI scrubber ash [171,172] or chemical mechanical polishing sludge [173]. The 28d strengths of hydrated systems blended with modified slag were comparable or higher than those of OPC. The HMs leachability of modified slag further declined, and the early strengths of blended cement-based products improved. The remained HMs (e.g., $\mathrm{Pb}$ and Zn) were immobilized in hydrated PC matrix, e.g., ettringite and C-S-H [174,175].

\subsection{Use as Precursors in Alkali-Activated Materials}

C-A-S-H, which immobilizes organic compounds and HMs, is also a key binding phase of alkali-activated materials (AAMs), e.g., alkali-activated calcium aluminosilicate [176,177]. Sodium hydroxide and sodium silicate are the most common activators to activate precursors-amorphous (calcium) aluminosilicate phases [178,179]. When precursors are calciumpoor, the key binding phase is sodium aluminosilicate hydrate (N-A-S-H), a nanosized gel, which also adsorbs toxic elements $[180,181]$. Zeolite, a secondary product in AAMs, also adsorbs organic matters [182] and toxic elements [183]. Sodium sulfate and sodium carbonate are also potential activators of AAMs [184]. However, their use results in slower activation and lower strengths of AAMs [185]. MSWI ash is potentially a partial or sole precursor of AAMs due to its presence of amorphous (calcium) aluminosilicate [186,187]. 
Similar to binders mentioned earlier, as building materials, AAM systems accommodate little untreated MSWI ash due to the large particle size and the presence of chloride, $\mathrm{HMs}$, and metallic Al. Unwashed Cl-rich MSWI BA was the sole precursor for synthesizing an AAM in [188]. The binding phase in this system was a mixture of C-A-S-H and N-A-S-H. The lack of mechanical properties and $\mathrm{Cl}$ leachability results makes utilizing unwashed MSWI ash in the production of reinforced concrete questionable. The presence of metallic $\mathrm{Al}$ in MSWI BA limits its incorporation in normal-weight concrete because the metallic Al-induced $\mathrm{H}_{2}$ gas reduces the density of AAMs (below $1000 \mathrm{~kg} / \mathrm{m}^{3}$ [189]). Wongsa et al. also used MSWI BA as the sole precursor to synthesize AAMs. The mortar exhibited $7 \mathrm{~d}$ and 28d compressive strengths of $9.2 \mathrm{MPa}$ and $10.6 \mathrm{MPa}$, respectively [190]. Thus, MSWI BA can be used to produce lightweight low-strength concrete as a precursor or aerating agent [191]. Wongsa et al. also used untreated BA as a coal fly ash substitute to synthesize AAM mortars. The maximum $7 \mathrm{~d}$ and $28 \mathrm{~d}$ compressive strengths were all observed at the $20 \mathrm{wt} . \%$ precursor substitution [190].

The density of pure MSWI ash-based pastes can be improved to over $1800 \mathrm{~kg} / \mathrm{m}^{3}$ with uniaxial pre-pressing at a few MPa (e.g., $5 \mathrm{MPa}$ [192]). Pressing removes excessive water and $\mathrm{H}_{2}$ induced pores in the binder matrix. Qiao et al. reported the pressinginduced densification of alkali-activated MSWI BA [193]. The compressive strengths reached $\sim 15 \mathrm{MPa}$ using thermally-treated $\left(800{ }^{\circ} \mathrm{C}\right) \mathrm{MSWI}$ BA due to the decomposition of $\mathrm{CaCO}_{3}$ in raw ash. Huang et al. compared the influences of different BA pretreatment methods on the synthesis of AAMs [194]. Alkali-soaking removed metallic Al in BA, and $700{ }^{\circ} \mathrm{C}$ was the optimal temperature for removing organic matters and improving BA reactivity. The $28 \mathrm{~d}$ compressive strength of the pure MSWI ash-based mortar reached $14 \mathrm{MPa}$ without pre-pressing. The 28d compressive strength increased to $53 \mathrm{MPa}$ when $40 \%$ MSWI BA was replaced by GGBFS. Follow-up studies found that the compressive strengths of hybrid AAMs were sensitive to alkali content [195], liquid/solid-state sodium silicate [196], $\mathrm{SiO}_{2} / \mathrm{Na}_{2} \mathrm{O}$ ratio [196], and curing conditions [186]. The variation of $28 \mathrm{~d}$ compressive strengths caused by these factors was over $35 \mathrm{MPa}$.

Ren et al. synthesized AAM pastes with unwashed MSWI FA as the sole precursor without pre-pressing [197]. The optimal $7 \mathrm{~d}$ compressive strength of pastes cured at $20^{\circ} \mathrm{C}$ was merely $5 \mathrm{MPa}$. Zheng et al. also activated pure unwashed MSWI FA at room temperature but pre-pressed the pastes [198]. The pre-pressed samples exhibited $7 \mathrm{~d}$ compressive strength of $20 \mathrm{MPa}$ by optimizing $\mathrm{Na} / \mathrm{Si} / \mathrm{Ai}$ ratios. While $\mathrm{HMs}$ (e.g., $\mathrm{Zn}, \mathrm{Cu}, \mathrm{Pb}$, and $\mathrm{Cr}$ ) in unwashed FA were immobilized, the systems were still Cl-rich. The low strength of the products may be explained by the low amorphous content and low reactivity of untreated MSWI FA and the presence of other detrimental impurities. Metallic Al may also remain in untreated MSWI FA; thus, incorporating untreated MSWI ash in AAMs synthesis may cause the expansion and cracking of binding systems [88]. Similar to coal fly ash, MSWI FA typically exhibits lower reactivity than GGBFS. Thus, the precursor replacement of GGBFS by MSWI FA leads to lower compressive strength and degree of reaction. Liu et al. showed a negative correlation between $3 \mathrm{~d}$ compressive strength and unwashed MSWI FA content of alkali-activated GGBFS pastes cured at $75{ }^{\circ} \mathrm{C}$ [48]. In other words, MSWI-FA-AAM exhibited higher strengths when MSWI FA was partially replaced with GGBFS due to lower water-to-effective binder ratios. Leaching results indicated that the GGBFS-MSWI FA hybrid AAMs could be used as nonreinforced building materials. Likewise, the partial replacement of MSWI FA with metakaolin (pure calcined clay, mainly amorphous aluminosilica) and silica fume also resulted in higher strengths. With $10 \mathrm{wt} \%$ MSWI FA replaced by metakaolin or silica fume, the $7 \mathrm{~d}$ compressive strengths of AAM pastes increased by $50 \%$ and $160 \%$, respectively $[197,199]$. Untreated MSWI FA also exhibited lower reactivity than coal fly ash in AAMs. $7 \mathrm{~d}$ compressive strength of $100{ }^{\circ} \mathrm{C}$ cured AAM concrete decreased from $58 \mathrm{MPa}$ to $10 \mathrm{MPa}$ when the MSWI FA-to-precursor ratio increased from 0 to $100 \%$ [200]. The leachability of $\mathrm{Cr}$, As, Ba, and $\mathrm{Hg}$ of the AAMs was within regulatory limits except for Se. 
Appropriate pretreatment, e.g., washing, also improves the performance of MSWI FA-AAM. After reducing $\mathrm{Cl}$ content from $19.6 \%$ to $1.6 \%$ by water-washing, the $7 \mathrm{~d}$ and $28 \mathrm{~d}$ compressive strengths of room temperature cured MSWI FA-AAM pastes increased by 15 and $45 \%$, respectively [59]. The AAM with washed FA exhibited a finer pore size distribution and lower $\mathrm{Cu}, \mathrm{Cr}$, and $\mathrm{Zn}$ leachability. Vitrificated MSWI FA, a homogenous slag with high amorphous content of calcium aluminosilicate, is potentially a high-quality precursor for producing AAMs. Further studies of this novel sustainable AAM are worthy.

It is worth iterating the global shortage of industrial byproduct SCMs, and the competition between blended PC and AAMs for SCMs demands. Coal fly ash and GGBFS are not truly sustainable for AAM production in regions/countries (e.g., California and Iceland) with a shortage of such industrial byproducts. Local areas (e.g., Wyoming and Australia) with excessive GGBFS or coal fly ash co-production may be suitable for accommodating MSWI ash in hybrid AAMs.

\subsection{Use as Aggregates}

The particle size distribution of BA falls in the range of concrete aggregates. However, raw MSWI BA is rarely used as normal aggregates due to the $\mathrm{H}_{2}$ gas-induced cracking [201] and an expansive gel from the alkali-silica reaction between glass residues in raw ash and alkaline pore solution [165]. Damage of cement matrix due to the presence of glass is less severe than that caused by the presence of metallic Al [202]. The leaching from raw ash also limits its direct use as aggregates. Pretreatment is required for the use of MSWI ash as aggregates.

Treated BA may not fully replace natural aggregates in mortar or concrete. A negative linear correlation between concrete compressive strength and gravel replacement level with water-washed BA was reported [203]. A full gravel replacement caused a 50\% reduction in $28 \mathrm{~d}$ compressive strength, which may be explained by the remaining metallic $\mathrm{Zn}$ and $\mathrm{Al}$ of washed ash. Similarly, carbonation-treated BA was used to replace $25 \%$ fine aggregates in mortars [36]. The $28 \mathrm{~d}$ compressive strength of the replaced group was merely half of the reference group, also due to the presence of metallic $\mathrm{Zn}$ and $\mathrm{Al}$. The toxic concentrations of leachates from treated-BA-containing mortars were below the regulatory limits with the exception of $\mathrm{Pb}$ and $\mathrm{Cu}$. After immersion into sodium hydroxide solution, metallic $\mathrm{Al}$ and $\mathrm{Zn}$ in BA were fully consumed. Concrete with $50 \%$ substitution of the well-treated BA aggregates still exhibited $10 \%$ lower $28 \mathrm{~d}$ compressive strength compared to the reference group [201]. The strength development of the BA-incorporated group after 28 days was even slower. The strength gap between concrete containing natural and BA-artificial aggregates may be relevant to aggregate shape and particle size distribution [204]. Further studies on dismantling the major barrier (e.g., low strength) to the use of treated BA as normal aggregates are encouraged.

Mangialardi investigated the influence of washing on sintered MSWI FA in the aggregates manufacture [115]. Sintering unwashed FA was ineffective for manufacturing aggregates due to the high leachability and low compressive strength $(\sim 5 \mathrm{MPa})$. A process combining washing, pre-pressing at $28 \mathrm{MPa}$, and sintering at $1140{ }^{\circ} \mathrm{C}$ yielded FA-based products with low leachability and high compressive strength (17-29 MPa). This product was claimed as normal weight aggregates. Unfortunately, further investigation on the influences of artificial aggregates on concrete mechanical properties remains explored.

Since the leachability of FA is higher than that of BA, FA and BA may be collectively treated to dilute the potential toxicity of MSWI ash as aggregates. After washing and crushing, Tian et al. separated combined ash into three fractions (particle sizes of 9.5-25 mm, 2-9.5 $\mathrm{mm}$, and $<2 \mathrm{~mm}$ ) to replace coarse gravel, medium gravel, and mortar sand [21]. The combined ash fine and medium aggregates at all substitution levels $(10 \%, 50 \%$, and $100 \%$ ) caused lower strength and higher porosity. $30 \%$ coarse gravel could be replaced by 9.5-25 mm combined ash without strength reduction. All HMs concentrations of product leachates complied with regulatory limits except $\mathrm{Cr}$. Because the coarse combined ash con- 
tains glass pieces, further investigation on alkali-silica reaction is suggested for evaluating the long-term performance of combined ash-incorporated concrete.

\section{Perspectives}

Social-environmental conflicts remain on the incineration of MSW as waste-derived fuels in cement kilns in terms of economic benefits, environmental concerns, health issues, and environmental justice issues $[205,206]$. The core of this anti-incineration of MSW in cement kilns are facilities in cement plants that were originally designed to produce cement clinker, not to minimize the air pollutants from MSW incineration [207]. MSW incineration in waste-to-energy plants is more suitable for sustainable waste management [208,209].

MSWI ash from waste-to-energy plants for cement and concrete production is a more suitable solution to environmental justice issues. The organic matter content in MSWI ash is noticeably reduced from unburnt MSW. The co-combustion of MSWI ash with limestone and clay in cement kilns would dilute the emissions of air pollutants in cement plant flue gas. Note that the fraction of raw ash in cement feedstock must be below the limit of alkalis and chloride. Further investigation on the species and concentration of emissions is needed and is essential to health impacts on communities neighboring cement plants. Cement manufacture contributes to over $85 \%$ of $\mathrm{CO}_{2}$ emissions and $\mathrm{HM}$ emissions in concrete production [210]. The partial cement replacement with well-treated MSWI ash lowers the environmental impacts of mortar and concrete production. The long-term performance and eco-performance (e.g., leachability) of MSWI ash-incorporated cement-based products deserve attention. The related studies would be critical to public health, particularly to neighborhoods that live in/by buildings and infrastructure made of MSWI ash-containing mortar and concrete.

The impacts of the utilization of MSWI ash on environmental justice may vary in different economic regions. The incineration of MSW in Europe is more common than that in the US [11]. Thus, the backlash to changing the roadmap of MSW landfilling versus MSWI ash utilization in Europe is lower than that in the US. For densely populated regions with shortages of landfilling capacities, e.g., New York City, New Jersey, and District of Columbia, the utilization of MSWI ash have a higher impact on environmental justice than less populated regions, such as Alaska and Wyoming. The regional difference in energy grids also affects the impacts of MSWI utilization ash on environmental justice, which can be more complicated. For regions with access to clean/renewable energy grid, the MSWI incineration-related emission (without appropriate treatments) may be an issue of environmental justice. For regions that use high carbon intensity electricity, the MSWI incineration may reduce the dependence on fossil fuels, thus lowering the environmental impacts of fossil fuels-related electricity generation.

Recycling treated MSWI ash as aggregates must be carefully evaluated as the products typically show inferior mechanical performance. Decision-makers must not ignore the competition between coarse MSWI ash and other solid wastes (e.g., construction and demolition waste [211]) as low-grade aggregates. It is worth comparing the performance of concrete incorporated with coarse MSWI ash and recycled aggregates. Coarse MSWI ash and cement-stabilized MSWI ash may be used for low-value applications, e.g., road base [42] or land reclamation [212]. The environmental impacts of these applications must be evaluated for seaside communities and relevant neighborhoods nearby to avoid secondary environmental justice issues. Thus, case studies regarding life-cycle assessments of MSWI ash utilization in POC, low-income, and other communities are essential and deserve deep investigation.

The fate of wastes generated from pretreatments of raw MSWI ash (e.g., toxic washing water, hazardous vapors, filtration cakes, and ground/sieved wastes) must not be ignored. The energy use and environmental impacts of the waste stream should be evaluated in life-cycle assessments. The allocation of the environmental burden into concrete production deserves further discussions, which are also critical to environmental justice. In addition, the allocation of energy use and environmental impacts of ash pretreatment also deserves 
further investigation. Superior ash pretreatment methods with low energy input and possible utilization of renewable electricity need to be developed to promote the upcycling of MSWI ash.

Some technical or economical driving forces in waste management and the concrete industry are needed to promote environmental justice indirectly or directly. Economic factors can be direct driving forces to the incineration of MSW and the utilization of MSWI ash. The higher cost of concrete production (e.g., higher cement prices) may favor the incorporation of MSWI ash into concrete. Taxing $\mathrm{CO}_{2}$ emissions of cement production and/or fossil fuels consumption and rising regulation fees of landfill disposals may facilitate the use of MSWI ash in the construction industry. More mature techniques are critical to stimulating the high-quality utilization of MSWI ash indirectly. Improved MSW sorting and optimized treatment of MSWI ash may ensure the higher quality of MSWI ash for its incorporation in concrete with less negative influences on performance. The outcomes (lower environmental impacts of concrete production, less MSW landfill, and/or less unused MSWI ash) would contribute to environmental justice.

\section{Concluding Remarks}

This paper has summarized recent important research findings related to municipal solid waste incineration ash that could be used to produce cement and concrete. Both waste management and concrete production contribute to environmental justice issues in terms of air pollutants, toxic emissions, and soil and water contamination. The incorporation of the ash in cement and concrete production can mitigate the environmental justice issues in the fields of waste management and construction. The wide use of raw ash to produce Portland cement and concrete is challenging and impractical. Bottom ash is typically nonhazardous but may contain chloride and metallic aluminum; both limit its use in the production of normal-weight standard-performance reinforced concrete. Municipal solid waste incineration fly ash is hazardous with a considerable fraction of toxic organic matters, heavy metals, alkalis, chloride, and sulfate. The incorporation of raw fly ash in cement disturbs cement setting, triggers rebar corrosion, and may contaminate cement-based products. The low density, high heterogeneity, and inappropriate size distribution of raw ash limit its incorporation in Portland cement and concrete. Raw ash may only be used as a raw material for producing alternative cement, which has a niche market.

Pretreatment of raw ash is commonly required before its incorporation in Portland cement and concrete for broad applications. Many pretreatment methods have been studied to improve the reactivity, remove toxic and detrimental impurities, improve the ash density, and optimize final size distribution. Washing is the most efficient and common method to remove toxic components, alkalis, chlorides, and metallic aluminum from raw ash at scale. Vitrification is the most efficient method to improve the reactivity and homogeneity of fly ash at the pilot scale. The improved homogeneity of fly ash slag may be suitable for high-volume production of cement/concrete, possibly at the industrial scale. The leachability of toxic components of treated ash typically complies with regulatory limits with few exceptions.

Portland cement and concrete incorporated with well-treated ash meet most of the regulatory limits for building materials or inert products. However, the mechanical properties of these products are usually inferior to products without ash incorporation, especially when ash is used as aggregates or substitutes for low-grade Portland cement. The use of treated ash as precursors of alkali-activated materials commonly undermines the mechanical properties and increases porosity. Treated ash is more suitable as an aerating agent in the synthesis of low-strength aerated alkali-activated materials. The utilization of treated ash must be appropriately designed for commercializing standard-performance products which are practical and profitable.

The enormous generation of municipal solid waste and incinerated ash ensures a robust supply chain for producing ash-containing construction materials. However, the large variability of raw ash, treated ash, and ash-incorporated products limit its large-scale 
deployment of ash incorporation products. For large-scale deployment, it is essential to ensure low variability in technical specifications. This is particularly critical to building and infrastructure materials due to their massive demand that economically viable development must fulfill. Some driving forces (technical or economic) in waste management and the concrete industry may lead to significant outcomes in environmental justice.

Funding: This work is supported by the Career Development Fund at LLNL. This work was performed under the auspices of the U.S. Department of Energy by Lawrence Livermore National Laboratory (contract No. DE-AC52-07NA27344).

Institutional Review Board Statement: Not applicable.

Informed Consent Statement: Not applicable.

Acknowledgments: The author acknowledges the Strategic Diversity and Inclusion program in LLNL, where thrives from diversity as each individual brings experiences and knowledge that enhances teamwork and productivity.

Conflicts of Interest: The author declares no conflict of interest.

\section{References}

1. Mohai, P.; Pellow, D.; Roberts, J.T. Environmental justice. Annu. Rev. Environ. Resour. 2009, 34, 405-430. [CrossRef]

2. Bullard, R.D. Quest for Environmental Justice; Sierra Club Books: San Francisco, CA, USA, 2005.

3. Bullard, R. Environmental Blackmail in Minority Communities. In Race and the Incidence of Environmental Hazards; Routledge: Oxfordshire, UK, 2019; pp. 82-95. [CrossRef]

4. Bullard, R.D.; Johnson, G.S.; Torres, A.O. Environmental Health and Racial Equity in the United States: Strategies for Building Environmentally Just, Sustainable, and Livable Communities; American Public Health Association: Washington, DC, USA, 2011.

5. Chambliss, S.E.; Pinon, C.P.; Messier, K.P.; LaFranchi, B.; Upperman, C.R.; Lunden, M.M.; Robinson, A.L.; Marshall, J.D.; Apte, J.S. Local- and regional-scale racial and ethnic disparities in air pollution determined by long-term mobile monitoring. ChemRxiv 2021. [CrossRef]

6. Middleton, C.; Allouche, J.; Gyawali, D.; Allen, S. The rise and implications of the water-energy-food nexus in Southeast Asia through an environmental justice lens. Water Altern. 2015, 1, 627-654.

7. Johnston, J.E.; Chau, K.; Franklin, M.; Cushing, L.J. Environmental Justice Dimensions of Oil and Gas Flaring in South Texas: Disproportionate Exposure among Hispanic communities. Environ. Sci. Technol. 2020, 54, 6289-6298. [CrossRef]

8. Chakraborty, J.; Maantay, J.A.; Brender, J.D. Disproportionate Proximity to Environmental Health Hazards: Methods, Models, and Measurement. Am. J. Public Health 2011, 101, S27-S36. [CrossRef]

9. Tessum, C.W.; Paolella, D.A.; Chambliss, S.E.; Apte, J.S.; Hill, J.D.; Marshall, J.D. PM2.5 polluters disproportionately and systemically affect people of color in the United States. Sci. Adv. 2021, 7, eabf4491. [CrossRef]

10. Thind, M.P.S.; Tessum, C.W.; Azevedo, I.L.; Marshall, J.D. Fine Particulate Air Pollution from Electricity Generation in the US: Health Impacts by Race, Income, and Geography. Environ. Sci. Technol. 2019, 53, 14010-14019. [CrossRef]

11. Petts, J. Enhancing environmental equity through decision-making: Learning from waste management. Local Environ. 2005, 10, 397-409. [CrossRef]

12. Harding, A.; Holdren, J.G. Environmental Equity and the Environmental Professional. Environ. Sci. Technol. 1993, 27, 1990-1992. [CrossRef]

13. Fricker, R.D.; Hengartner, N.W. Environmental equity and the distribution of toxic release inventory and other environ-mentally undesirable sites in metropolitan New York City. Environ. Ecol. Stat. 2001, 8, 33-52. [CrossRef]

14. Bullard, R.D. Solid Waste Sites and the Black Houston Community. Sociol. Inq. 1983, 53, 273-288. [CrossRef]

15. Bullard, R.D.; Mohai, P.; Saha, R.; Wright, B. Toxic wastes and race at twenty: Why race still matters after all of these years. Envtl. L. 2008, 38, 371 .

16. Bullard, R.D. Environmental justice for all: It's the right thing to do. J. Envtl. L. Litig. 1994, 9, 281.

17. De Feo, G.; De Gisi, S.; Williams, I.D. Public perception of odour and environmental pollution attributed to MSW treat-ment and disposal facilities: A case study. Waste Manag. 2013, 33, 974-987. [CrossRef] [PubMed]

18. Palmiotto, M.; Fattore, E.; Paiano, V.; Celeste, G.; Colombo, A.; Davoli, E. Influence of a municipal solid waste landfill in the surrounding environment: Toxicological risk and odor nuisance effects. Environ. Int. 2014, 68, 16-24. [CrossRef] [PubMed]

19. Sorlini, S.; Collivignarelli, M.C.; Abbà, A. Leaching behaviour of municipal solid waste incineration bottom ash: From granular material to monolithic concrete. Waste Manag. Res. 2017, 35, 978-990. [CrossRef]

20. Bullard, R.D. Environmental Justice in the 21st Century. Debating Earth 2005, 3222-3356.

21. Tian, Y.; Bourtsalas, A.; Kawashima, S.; Ma, S.; Themelis, N.J. Performance of structural concrete using Waste-to-Energy (WTE) combined ash. Waste Manag. 2020, 118, 180-189. [CrossRef]

22. Monteiro, P.J.M.; Miller, S.; Horvath, A. Towards sustainable concrete. Nat. Mater. 2017, 16, 698-699. [CrossRef] [PubMed] 
23. USGS. Mineral Commodity Summaries; Government Printing Office: Washington, DC, USA, 2019.

24. Li, J.; Zhang, W.; Li, C.; Monteiro, P.J. Green concrete containing diatomaceous earth and limestone: Workability, mechanical properties, and life-cycle assessment. J. Clean. Prod. 2019, 223, 662-679. [CrossRef]

25. Miller, S.A.; Moore, F.C. Climate and health damages from global concrete production. Nat. Clim. Chang. 2020, 10, 439-443. [CrossRef]

26. Brinkman, L.A.; Miller, S.A. Environmental impacts and environmental justice implications of supplementary cementi-tious materials for use in concrete. Environ. Res. Infrastruct. Sustain. 2021, 1, 025003. [CrossRef]

27. Haiying, Z.; Youcai, Z.; Jingyu, Q. Utilization of municipal solid waste incineration (MSWI) fly ash in ceramic brick: Product characterization and environmental toxicity. Waste Manag. 2011, 31, 331-341. [CrossRef] [PubMed]

28. Deng, Y.; Gong, B.; Chao, Y.; Dong, T.; Yang, W.; Hong, M.; Shi, X.; Wang, G.; Jin, Y.; Chen, Z.-G. Sustainable utilization of municipal solid waste incineration fly ash for ceramic bricks with eco-friendly biosafety. Mater. Today Sustain. 2018, 1, 32-38. [CrossRef]

29. Haiying, Z.; Youcai, Z.; Jingyu, Q. Study on use of MSWI fly ash in ceramic tile. J. Hazard. Mater. 2007, 141, 106-114. [CrossRef]

30. Tang, P.; Chen, W.; Xuan, D.; Cheng, H.; Poon, C.S.; Tsang, D.C. Immobilization of hazardous municipal solid waste in-cineration fly ash by novel alternative binders derived from cementitious waste. J. Hazard. Mater. 2020, 393, 122386. [CrossRef]

31. Zhang, Y.; Wang, L.; Chen, L.; Ma, B.; Zhang, Y.; Ni, W.; Tsang, D.C. Treatment of municipal solid waste incineration fly ash: State-of-the-art technologies and future perspectives. J. Hazard. Mater. 2021, 411, 125132. [CrossRef] [PubMed]

32. Aubert, J.; Husson, B.; Vaquier, A. Use of municipal solid waste incineration fly ash in concrete. Cem. Concr. Res. 2004, 34, 957-963. [CrossRef]

33. Sun, X.; Li, J.; Zhao, X.; Zhu, B.; Zhang, G. A Review on the Management of Municipal Solid Waste Fly Ash in American. Procedia Environ. Sci. 2016, 31, 535-540. [CrossRef]

34. Siddique, R. Use of municipal solid waste ash in concrete. Resour. Conserv. Recycl. 2010, 55, 83-91. [CrossRef]

35. Guo, X.; Shi, H.; Hu, W.; Wu, K. Durability and microstructure of CSA cement-based materials from MSWI fly ash. Cem. Concr. Compos. 2014, 46, 26-31. [CrossRef]

36. Saikia, N.; Cornelis, G.; Mertens, G.; Elsen, J.; Van Balen, K.; Van Gerven, T.; Vandecasteele, C. Assessment of Pb-slag, MSWI bottom ash and boiler and fly ash for using as a fine aggregate in cement mortar. J. Hazard. Mater. 2008, 154, 766-777. [CrossRef]

37. Joseph, A.M.; Snellings, R.; Nielsen, P.; Matthys, S.; De Belie, N. Pre-treatment and utilisation of municipal solid waste incineration bottom ashes towards a circular economy. Constr. Build. Mater. 2020, 260, 120485. [CrossRef]

38. Wang, P.; Hu, Y.; Cheng, H. Municipal solid waste (MSW) incineration fly ash as an important source of heavy metal pollution in China. Environ. Pollut. 2019, 252, 461-475. [CrossRef]

39. Zhang, Y.; Ma, Z.; Fang, Z.; Qian, Y.; Zhong, P.; Yan, J. Review of harmless treatment of municipal solid waste incineration fly ash. Waste Dispos. Sustain. Energy 2020, 2, 1-25. [CrossRef]

40. Siddique, R. Utilization of municipal solid waste (MSW) ash in cement and mortar. Resour. Conserv. Recycl. 2010, 54, 1037-1047. [CrossRef]

41. Ginés, O.; Chimenos, J.M.; Vizcarro, A.; Formosa, J.; Rosell, J.R. Combined use of MSWI bottom ash and fly ash as aggregate in concrete formulation: Environmental and mechanical considerations. J. Hazard. Mater. 2009, 169, 643-650. [CrossRef]

42. Lu, Y.; Tian, A.; Zhang, J.; Ang, Y.; Shi, P.; Tang, Q.; Huang, Y. Physical and Chemical Properties, Pretreatment, and Recycling of Municipal Solid Waste Incineration Fly Ash and Bottom Ash for Highway Engineering: A Literature Review. Adv. Civ. Eng. 2020, 2020, 886134.

43. Yang, S.; Saffarzadeh, A.; Shimaoka, T.; Kawano, T. Existence of $\mathrm{Cl}$ in municipal solid waste incineration bottom ash and dechlorination effect of thermal treatment. J. Hazard. Mater. 2014, 267, 214-220. [CrossRef] [PubMed]

44. Speiser, C.; Baumann, T.; Niessner, R. Morphological and Chemical Characterization of Calcium-Hydrate Phases Formed in Alteration Processes of Deposited Municipal Solid Waste Incinerator Bottom Ash. Environ. Sci. Technol. 2000, 34, 5030-5037. [CrossRef]

45. Dou, X.; Ren, F.; Nguyen, M.Q.; Ahamed, A.; Yin, K.; Chan, W.P.; Chang, V.W.-C. Review of MSWI bottom ash utilization from perspectives of collective characterization, treatment and existing application. Renew. Sustain. Energy Rev. 2017, 79, 24-38. [CrossRef]

46. Maldonado-Alameda, A.; Paloma, J.G.; Sedlackova, A.S.; Formosa, J.; Chimenos, J. Municipal solid waste incineration bottom ash as alkali-activated cement precursor depending on particle size. J. Clean. Prod. 2020, 242, 118443. [CrossRef]

47. Rémond, S.; Pimienta, P.; Bentz, D.P. Effects of the incorporation of Municipal Solid Waste Incineration fly ash in cement pastes and mortars: I. Experimental study. Cem. Concr. Res. 2002, 32, 303-311. [CrossRef]

48. Liu, Y.; Zhu, W.; Yang, E.-H. Alkali-activated ground granulated blast-furnace slag incorporating incinerator fly ash as a potential binder. Constr. Build. Mater. 2016, 112, 1005-1012. [CrossRef]

49. Pan, J.R.; Huang, C.; Kuo, J.-J.; Lin, S.-H. Recycling MSWI bottom and fly ash as raw materials for Portland cement. Waste Manag. 2008, 28, 1113-1118. [CrossRef] [PubMed]

50. Shan, C.; Jing, Z.; Pan, L.; Zhou, L.; Pan, X.; Lu, L. Hydrothermal solidification of municipal solid waste incineration fly ash. Res. Chem. Intermed. 2011, 37, 551-565. [CrossRef]

51. Liu, B.; Yang, Q.-W.; Zhang, S.-G. Integrated utilization of municipal solid waste incineration fly ash and bottom ash for preparation of foam glass-ceramics. Rare Met. 2019, 38, 914-921. [CrossRef] 
52. Ashok, J.; Das, S.; Yeo, T.; Dewangan, N.; Kawi, S. Incinerator bottom ash derived from municipal solid waste as a potential catalytic support for biomass tar reforming. Waste Manag. 2018, 82, 249-257. [CrossRef]

53. Quina, M.J.; Bordado, J.C.; Quinta-Ferreira, R.M. The influence of $\mathrm{pH}$ on the leaching behaviour of inorganic components from municipal solid waste APC residues. Waste Manag. 2009, 29, 2483-2493. [CrossRef]

54. Mu, Y.; Saffarzadeh, A.; Shimaoka, T. Influence of ignition process on mineral phase transformation in municipal solid waste incineration (MSWI) fly ash: Implications for estimating loss-on-ignition (LOI). Waste Manag. 2017, 59, 222-228. [CrossRef]

55. Lam, C.H.K.; Ip, A.W.M.; Barford, J.P.; McKay, G. Use of Incineration MSW Ash: A Review. Sustainability 2010, 2, 1943-1968. [CrossRef]

56. Wei, Y.; Shimaoka, T.; Saffarzadeh, A.; Takahashi, F. Mineralogical characterization of municipal solid waste incineration bottom ash with an emphasis on heavy metal-bearing phases. J. Hazard. Mater. 2011, 187, 534-543. [CrossRef]

57. Tang, J.; Steenari, B.-M. Leaching optimization of municipal solid waste incineration ash for resource recovery: A case study of $\mathrm{Cu}, \mathrm{Zn}, \mathrm{Pb}$ and $\mathrm{Cd}$. Waste Manag. 2016, 48, 315-322. [CrossRef]

58. Wang, F.-H.; Zhang, F.; Chen, Y.-J.; Gao, J.; Zhao, B. A comparative study on the heavy metal solidification/stabilization performance of four chemical solidifying agents in municipal solid waste incineration fly ash. J. Hazard. Mater. 2015, 300, 451-458. [CrossRef]

59. Zheng, L.; Wang, C.; Wang, W.; Shi, Y.; Gao, X. Immobilization of MSWI fly ash through geopolymerization: Effects of water-wash. Waste Manag. 2011, 31, 311-317. [CrossRef]

60. Vollpracht, A.; Lothenbach, B.; Snellings, R.; Haufe, J. The pore solution of blended cements: A review. Mater. Struct. 2016, 49, 3341-3367. [CrossRef]

61. Mehta, P.K.; Monteiro, P.J. Concrete: Microstructure, Properties, and Materials; McGraw-Hill Education: New York, NY, USA, 2014.

62. Fan, C.; Miller, S. Reducing greenhouse gas emissions for prescribed concrete compressive strength. Constr. Build. Mater. 2018, 167, 918-928. [CrossRef]

63. Li, J.; Zhang, W.; Li, C.; Monteiro, P.J. Eco-friendly mortar with high-volume diatomite and fly ash: Performance and life-cycle assessment with regional variability. J. Clean. Prod. 2020, 261, 121224. [CrossRef]

64. Monteiro, P.J.; Geng, G.; Marchon, D.; Li, J.; Alapati, P.; Kurtis, K.E.; Qomi, M.J.A. Advances in characterizing and understanding the microstructure of cementitious materials. Cem. Concr. Res. 2019, 124, 105806. [CrossRef]

65. Li, J.; Zhang, W.; Monteiro, P.J.M. Structure and Intrinsic Mechanical Properties of Nanocrystalline Calcium Silicate Hydrate. ACS Sustain. Chem. Eng. 2020, 8, 12453-12461. [CrossRef]

66. Li, J.; Geng, G.; Zhang, W.; Yu, Y.S.; Shapiro, D.A.; Monteiro, P.J.M. The Hydration of beta- and alpha(H)'-Dicalcium Silicates: An X-ray Spectromicroscopic Study. ACS Sustain. Chem. Eng. 2019, 7, 2316-2326. [CrossRef]

67. Skinner, L.B.; Chae, S.R.; Benmore, C.J.; Wenk, H.R.; Monteiro, P.J.M. Nanostructure of Calcium Silicate Hydrates in Cements. Phys. Rev. Lett. 2010, 104, 195502. [CrossRef]

68. Li, J.; Geng, G.; Myers, R.; Yu, Y.-S.; Shapiro, D.; Carraro, C.; Maboudian, R.; Monteiro, P.J. The chemistry and structure of calcium (alumino) silicate hydrate: A study by XANES, ptychographic imaging, and wide- and small-angle scattering. Cem. Concr. Res. 2019, 115, 367-378. [CrossRef]

69. Wu, J.; Zhu, Y.-J.; Chen, F. Ultrathin Calcium Silicate Hydrate Nanosheets with Large Specific Surface Areas: Synthesis, Crystallization, Layered Self-Assembly and Applications as Excellent Adsorbents for Drug, Protein, and Metal Ions. Small 2013, 9, 2911-2925. [CrossRef] [PubMed]

70. Wu, J.; Zhu, Y.J.; Cao, S.W.; Chen, F. Hierachically nanostructured mesoporous spheres of calcium silicate hydrate: Surfactant-free sonochemical synthesis and drug-delivery system with ultrahigh drug-loading capacity. Adv. Mater. 2010, 22, 749-753. [CrossRef] [PubMed]

71. Ma, B.; Fernandez-Martinez, A.; Wang, K.; Madé, B.; Hénocq, P.; Tisserand, D.; Bureau, S.; Charlet, L. Selenite Sorption on Hydrated CEM-V/A Cement in the Presence of Steel Corrosion Products: Redox vs. Nonredox Sorption. Environ. Sci. Technol. 2020, 54, 2344-2352. [CrossRef]

72. Ma, B.; Charlet, L.; Fernandez-Martinez, A.; Kang, M.; Madé, B. A review of the retention mechanisms of redox-sensitive radionuclides in multi-barrier systems. Appl. Geochem. 2019, 100, 414-431. [CrossRef]

73. Labhasetwar, N.; Shrivastava, O. $\mathrm{Ca}^{2+} \rightleftharpoons \mathrm{Pb}^{2+}$ exchange reaction of calcium silicate hydrate: $\mathrm{Ca}_{5} \mathrm{Si}_{6} \mathrm{O}_{18} \mathrm{H}_{2} 4 \mathrm{H}_{2} \mathrm{O}$. J. Mater. Sci. 1989, 24, 4359-4362. [CrossRef]

74. Myneni, S.C.; Traina, S.J.; Logan, T.J.; Waychunas, G.A. Oxyanion behavior in alkaline environments: Sorption and de-sorption of arsenate in ettringite. Environ. Sci. Technol. 1997, 31, 1761-1768. [CrossRef]

75. Lothenbach, B.; Kulik, D.A.; Matschei, T.; Balonis, M.; Baquerizo, L.; Dilnesa, B.; Miron, G.; Myers, R.J. Cemdata18: A chemical thermodynamic database for hydrated Portland cements and alkali-activated materials. Cem. Concr. Res. 2019, 115, 472-506. [CrossRef]

76. Li, Y.; Li, Y.Q.; Shi, T.F.; Li, J.Q. Experimental study on mechanical properties and fracture toughness of magnesium phosphate cement. Constr. Build. Mater. 2015, 96, 346-352. [CrossRef]

77. Su, Y.; Yang, J.M.; Liu, D.B.; Zhen, S.C.; Lin, N.X.; Zhou, Y.X. Effects of municipal solid waste incineration fly ash on solidification/stabilization of $\mathrm{Cd}$ and $\mathrm{Pb}$ by magnesium potassium phosphate cement. J. Environ. Chem. Eng. 2016, 4, 259-265. [CrossRef] 
78. Li, Y.; Shi, T.; Li, J. Effects of fly ash and quartz sand on water-resistance and salt-resistance of magnesium phosphate cement. Constr. Build. Mater. 2016, 105, 384-390. [CrossRef]

79. Jin, Q.; Hordern, S.L.; Tang, Y.; Kurtis, K.E. NOx sequestration by calcium aluminate cementitious materials. Cem. Concr. Res. 2021, 142, 106381. [CrossRef]

80. Navarro-Blasco, I.; Duran, A.; Sirera, R.; Fernández, J.M.; Alvarez, J. Solidification/stabilization of toxic metals in calcium aluminate cement matrices. J. Hazard. Mater. 2013, 260, 89-103. [CrossRef]

81. Geng, G.; Li, J.; Yu, Y.-S.; Shapiro, D.A.; Kilcoyne, D.A.; Monteiro, P.J. Nanometer-Resolved Spectroscopic Study Reveals the Conversion Mechanism of $\mathrm{CaO} \cdot \mathrm{Al}_{2} \mathrm{O}_{3} \cdot 10 \mathrm{H}_{2} \mathrm{O}$ to $2 \mathrm{CaO} \cdot \mathrm{Al}_{2} \mathrm{O}_{3} \cdot 8 \mathrm{H}_{2} \mathrm{O}$ and $3 \mathrm{CaO} \cdot \mathrm{Al}_{2} \mathrm{O}_{3} \cdot 6 \mathrm{H}_{2} \mathrm{O}$ at an Elevated Temperature. Cryst. Growth Des. 2017, 17, 4246-4253. [CrossRef]

82. Miller, S.; Horvath, A.; Monteiro, P.J.M. Readily implementable techniques can cut annual $\mathrm{CO}_{2}$ emissions from the production of concrete by over 20\%. Environ. Res. Lett. 2016, 11, 074029. [CrossRef]

83. Alam, Q.; Schollbach, K.; van Hoek, C.; van der Laan, S.; de Wolf, T.; Brouwers, H. In-depth mineralogical quantification of MSWI bottom ash phases and their association with potentially toxic elements. Waste Manag. 2019, 87, 1-12. [CrossRef]

84. Bayuseno, A.P.; Schmahl, W.W. Characterization of MSWI fly ash through mineralogy and water extraction. Resour. Conserv. Recycl. 2011, 55, 524-534. [CrossRef]

85. Alderete, N.; Joseph, A.; Heede, P.V.D.; Matthys, S.; De Belie, N. Effective and sustainable use of municipal solid waste incineration bottom ash in concrete regarding strength and durability. Resour. Conserv. Recycl. 2021, 167, 105356. [CrossRef]

86. Lederer, J.; Trinkel, V.; Fellner, J. Wide-scale utilization of MSWI fly ashes in cement production and its impact on average heavy metal contents in cements: The case of Austria. Waste Manag. 2017, 60, 247-258. [CrossRef]

87. Hay, R.; Ostertag, C.P. On utilization and mechanisms of waste aluminium in mitigating alkali-silica reaction (ASR) in concrete. J. Clean. Prod. 2019, 212, 864-879. [CrossRef]

88. Tian, X.; Rao, F.; León-Patiño, C.A.; Song, S. Effects of aluminum on the expansion and microstructure of alkali-activated MSWI fly ash-based pastes. Chemosphere 2020, 240, 124986. [CrossRef]

89. Nguyen, W.; Duncan, J.F.; Jen, G.; Ostertag, C.P. Influence of matrix cracking and hybrid fiber reinforcement on the corro-sion initiation and propagation behaviors of reinforced concrete. Corros. Sci. 2018, 140, 168-181. [CrossRef]

90. Myers, R.J.; Geng, G.; Li, J.; Rodríguez, E.D.; Ha, J.; Kidkhunthod, P.; Sposito, G.; Lammers, L.N.; Kirchheim, A.P.; Monteiro, P.J.M. Role of Adsorption Phenomena in Cubic Tricalcium Aluminate Dissolution. Langmuir 2016, 33, 45-55. [CrossRef] [PubMed]

91. Kirchheim, A.P.; Rodríguez, E.D.; Myers, R.J.; Gobbo, L.A.; Monteiro, P.J.M.; Dal Molin, D.C.C.; De Souza, R.B.; Cincotto, M.A. Effect of gypsum on the early hydration of cubic and Na-doped orthorhombic tricalcium aluminate. Materials 2018, 11, 568. [CrossRef] [PubMed]

92. Luo, H.; Cheng, Y.; He, D.; Yang, E.-H. Review of leaching behavior of municipal solid waste incineration (MSWI) ash. Sci. Total Environ. 2019, 668, 90-103. [CrossRef] [PubMed]

93. Zhang, Y.; Cetin, B.; Likos, W.; Edil, T. Impacts of $\mathrm{pH}$ on leaching potential of elements from MSW incineration fly ash. Fuel 2016, 184, 815-825. [CrossRef]

94. De Weerdt, K.; Plusquellec, G.; Revert, A.B.; Geiker, M.; Lothenbach, B. Effect of carbonation on the pore solution of mor-tar. Cem. Concr. Res. 2019, 118, 38-56. [CrossRef]

95. Luo, H.; Wu, Y.; Zhao, A.; Kumar, A.; Liu, Y.; Cao, B.; Yang, E.-H. Hydrothermally synthesized porous materials from municipal solid waste incineration bottom ash and their interfacial interactions with chloroaromatic compounds. J. Clean. Prod. 2017, 162, 411-419. [CrossRef]

96. Sposito, G. The Chemistry of Soils; Oxford University Press: Oxford, UK, 2008.

97. Dove, P.M.; Han, N.; Wallace, A.F.; De Yoreo, J.J. Kinetics of amorphous silica dissolution and the paradox of the silica polymorphs. Proc. Natl. Acad. Sci. USA 2008, 105, 9903-9908. [CrossRef] [PubMed]

98. Bullard, J.W.; Jin, Q.; Snyder, K.A. How do specific surface area and particle size distribution change when granular media dissolve? Chem. Eng. J. 2021, 406, 127098. [CrossRef]

99. Dijkstra, J.J.; Van Zomeren, A.; Meeussen, J.C.L.; Comans, R.N.J. Effect of Accelerated Aging of MSWI Bottom Ash on the Leaching Mechanisms of Copper and Molybdenum. Environ. Sci. Technol. 2006, 40, 4481-4487. [CrossRef] [PubMed]

100. He, P.-J.; Pu, H.-X.; Shao, L.-M.; Zhang, H. Impact of co-landfill proportion of bottom ash and municipal solid waste composition on the leachate characteristics during the acidogenesis phase. Waste Manag. 2017, 69, 232-241. [CrossRef] [PubMed]

101. Kjeldsen, P.; Barlaz, M.A.; Rooker, A.P.; Baun, A.; Ledin, A.; Christensen, T.H. Present and Long-Term Composition of MSW Landfill Leachate: A Review. Crit. Rev. Environ. Sci. Technol. 2002, 32, 297-336. [CrossRef]

102. Deng, D.; Qiao, J.; Liu, M.; Kołodyńska, D.; Zhang, M.; Dionysiou, D.D.; Ju, Y.; Ma, J.; Chang, M.-b. Detoxification of municipal solid waste incinerator (MSWI) fly ash by single-mode microwave (MW) irradiation: Addition of urea on the degradation of Dioxin and mechanism. J. Hazard. Mater. 2019, 369, 279-289. [CrossRef]

103. Weidemann, E.; Lundin, L.; Boily, J.-F. Thermal decomposition of municipal solid waste fly ash and desorption of poly-chlorinated dibenzo-p-dioxins and furans from fly ash surfaces. Environ. Sci. Pollut. Res. 2016, 23, 22843-22851. [CrossRef]

104. Guimaraes, A.; Okuda, T.; Nishijima, W.; Okada, M. Organic carbon leaching behavior from incinerator bottom ash. J. Hazard. Mater. 2006, 137, 1096-1101. [CrossRef]

105. Biganzoli, L.; Ilyas, A.; van Praagh, M.; Persson, K.M.; Grosso, M. Aluminium recovery vs. hydrogen production as re-source recovery options for fine MSWI bottom ash fraction. Waste Manag. 2013, 33, 1174-1181. [CrossRef] 
106. Mulder, E. Pre-Treatment of MSWI fly ash for useful application. Waste Manag. 1996, 16, 181-184. [CrossRef]

107. Mao, Y.; Wu, H.; Wang, W.; Jia, M.; Che, X. Pretreatment of municipal solid waste incineration fly ash and preparation of solid waste source sulphoaluminate cementitious material. J. Hazard. Mater. 2020, 385, 121580. [CrossRef] [PubMed]

108. Chen, X.; Bi, Y.; Zhang, H.; Wang, J. Chlorides Removal and Control through Water-washing Process on MSWI Fly Ash. Procedia Environ. Sci. 2016, 31, 560-566. [CrossRef]

109. Chimenos, J.; Fernandez, A.I.; Cervantes, A.; Miralles, L.; Fernández, M.; Espiell, F. Optimizing the APC residue washing process to minimize the release of chloride and heavy metals. Waste Manag. 2005, 25, 686-693. [CrossRef]

110. Piantone, P.; Bodénan, F.; Chatelet-Snidaro, L. Mineralogical study of secondary mineral phases from weathered MSWI bottom ash: Implications for the modelling and trapping of heavy metals. Appl. Geochem. 2004, 19, 1891-1904. [CrossRef]

111. Saffarzadeh, A.; Arumugam, N.; Shimaoka, T. Aluminum and aluminum alloys in municipal solid waste incineration (MSWI) bottom ash: A potential source for the production of hydrogen gas. Int. J. Hydrogen Energy 2016, 41, 820-831. [CrossRef]

112. Kurashima, K.; Matsuda, K.; Kumagai, S.; Kameda, T.; Saito, Y.; Yoshioka, T. A combined kinetic and thermodynamic ap-proach for interpreting the complex interactions during chloride volatilization of heavy metals in municipal solid waste fly ash. Waste Manag. 2019, 87, 204-217. [CrossRef]

113. Chen, W.-S.; Chang, F.-C.; Shen, Y.-H.; Tsai, M.-S.; Ko, C.-H. Removal of chloride from MSWI fly ash. J. Hazard. Mater. 2012, 237, 116-120. [CrossRef]

114. Chen, W.; Kirkelund, G.M.; Jensen, P.E.; Ottosen, L.M. Comparison of different MSWI fly ash treatment processes on the thermal behavior of As, $\mathrm{Cr}, \mathrm{Pb}$ and $\mathrm{Zn}$ in the ash. Waste Manag. 2017, 68, 240-251. [CrossRef]

115. Mangialardi, T. Sintering of MSW fly ash for reuse as a concrete aggregate. J. Hazard. Mater. 2001, 87, 225-239. [CrossRef]

116. Lin, K.L. Feasibility study of using brick made from municipal solid waste incinerator fly ash slag. J. Hazard. Mater. 2006, 137, 1810-1816. [CrossRef]

117. Wang, K.; Lin, K.; Lee, T.; Tzeng, B. The hydration characteristics when C2S is present in MSWI fly ash slag. Cem. Concr. Compos. 2004, 26, 323-330. [CrossRef]

118. Stabile, P.; Bello, M.; Petrelli, M.; Paris, E.; Carroll, M. Vitrification treatment of municipal solid waste bottom ash. Waste Manag. 2019, 95, 250-258. [CrossRef] [PubMed]

119. Lin, K.; Wang, K.; Lee, T.; Tzeng, B. The hydration characteristics of MSWI fly ash slag present in C 3 S. Cem. Concr. Res. 2003, 33, 957-964. [CrossRef]

120. Lin, K.-L. The influence of municipal solid waste incinerator fly ash slag blended in cement pastes. Cem. Concr. Res. 2005, 35, 979-986. [CrossRef]

121. Sharifikolouei, E.; Baino, F.; Salvo, M.; Tommasi, T.; Pirone, R.; Fino, D.; Ferraris, M. Vitrification of municipal solid waste incineration fly ash: An approach to find the successful batch compositions. Ceram. Int. 2021, 47, 7738-7744. [CrossRef]

122. Gao, J.; Dong, C.; Wang, X.; Zhu, Y.; Zhao, Y.; Lin, Y.; Hu, X. Effect of additives on melting temperature and energy consumption of municipal solid waste incineration fly ash. Waste Manag. Res. 2021, 0734242X20985610.

123. Gao, J.; Dong, C.; Zhao, Y.; Hu, X.; Qin, W.; Wang, X.; Zhang, J.; Xue, J.; Zhang, X. Vitrification of municipal solid waste incineration fly ash with $\mathrm{B}_{2} \mathrm{O}_{3}$ as a fluxing agent. Waste Manag. 2020, 102, 932-938. [CrossRef]

124. Ma, W.; Fang, Y.; Chen, D.; Chen, G.; Xu, Y.; Sheng, H.; Zhou, Z. Volatilization and leaching behavior of heavy metals in MSW incineration fly ash in a DC arc plasma furnace. Fuel 2017, 210, 145-153. [CrossRef]

125. Yamaguchi, H.; Shibuya, E.; Kanamaru, Y.; Uyama, K.; Nishioka, M.; Yamasaki, N. Hydrothermal decomposition of PCDDs/PCDFs in MSWI fly ash. Chemosphere 1996, 32, 203-208. [CrossRef]

126. Qiu, Q.; Jiang, X.; Lv, G.; Chen, Z.; Lu, S.; Ni, M.; Yan, J.; Deng, X. Adsorption of heavy metal ions using zeolite materials of municipal solid waste incineration fly ash modified by microwave-assisted hydrothermal treatment. Powder Technol. 2018, 335, 156-163. [CrossRef]

127. Bayuseno, A.P.; Schmahl, W.; Müllejans, T. Hydrothermal processing of MSWI Fly Ash-towards new stable minerals and fixation of heavy metals. J. Hazard. Mater. 2009, 167, 250-259. [CrossRef] [PubMed]

128. Jing, Z.; Fan, X.; Zhou, L.; Fan, J.; Zhang, Y.; Pan, X.; Ishida, E.H. Hydrothermal solidification behavior of municipal solid waste incineration bottom ash without any additives. Waste Manag. 2013, 33, 1182-1189. [CrossRef]

129. Qiu, Q.; Jiang, X.; Chen, Z.; Lu, S.; Ni, M. Microwave-Assisted Hydrothermal Treatment with Soluble Phosphate Added for Heavy Metals Solidification in MSWI Fly Ash. Energy Fuels 2017, 31, 5222-5232. [CrossRef]

130. Bertolini, L.; Carsana, M.; Cassago, D.; Curzio, A.Q.; Collepardi, M. MSWI ashes as mineral additions in concrete. Cem. Concr. Res. 2004, 34, 1899-1906. [CrossRef]

131. Wang, W.; Gao, X.; Li, T.; Cheng, S.; Yang, H.; Qiao, Y. Stabilization of heavy metals in fly ashes from municipal solid waste incineration via wet milling. Fuel 2018, 216, 153-159. [CrossRef]

132. Chen, C.-G.; Sun, C.-J.; Gau, S.-H.; Wu, C.-W.; Chen, Y.-L. The effects of the mechanical-chemical stabilization process for municipal solid waste incinerator fly ash on the chemical reactions in cement paste. Waste Manag. 2013, 33, 858-865. [CrossRef]

133. Ni, P.; Xiong, Z.; Tian, C.; Li, H.; Zhao, Y.; Zhang, J.; Zheng, C. Influence of carbonation under oxy-fuel combustion flue gas on the leachability of heavy metals in MSWI fly ash. Waste Manag. 2017, 67, 171-180. [CrossRef]

134. Cornelis, G.; Van Gerven, T.; Vandecasteele, C. Antimony leaching from uncarbonated and carbonated MSWI bottom ash. J. Hazard. Mater. 2006, 137, 1284-1292. [CrossRef] 
135. Li, X.; Bertos, M.F.; Hills, C.D.; Carey, P.J.; Simon, S. Accelerated carbonation of municipal solid waste incineration fly ashes. Waste Manag. 2007, 27, 1200-1206. [CrossRef] [PubMed]

136. Hay, R.; Celik, K. Hydration, carbonation, strength development and corrosion resistance of reactive MgO cement-based composites. Cem. Concr. Res. 2020, 128, 105941. [CrossRef]

137. Ruan, S.; Unluer, C. Influence of supplementary cementitious materials on the performance and environmental impacts of reactive magnesia cement concrete. J. Clean. Prod. 2017, 159, 62-73. [CrossRef]

138. Hay, R.; Celik, K. Accelerated carbonation of reactive magnesium oxide cement (RMC)-based composite with supercritical carbon dioxide (scCO2). J. Clean. Prod. 2020, 248, 119282. [CrossRef]

139. Hay, R.; Kashwani, G.; Celik, K. Carbonation, strength development, and characterization of calcined limestone as a po-tential construction material. Cem. Concr. Res. 2021, 139, 106263. [CrossRef]

140. Monteiro, P.J.; Clodic, L.; Battocchio, F.; Kanitpanyacharoen, W.; Chae, S.R.; Ha, J.; Wenk, H.-R. Incorporating carbon sequestration materials in civil infrastructure: A micro and nano-structural analysis. Cem. Concr. Compos. 2013, 40, 14-20. [CrossRef]

141. Svensson, K.; Neumann, A.; Menezes, F.F.; Lempp, C.; Pöllmann, H. The Conversion of Wollastonite to $\mathrm{CaCO}_{3} \mathrm{Considering}$ Its Use for CCS Application as Cementitious Material. Appl. Sci. 2018, 8, 304. [CrossRef]

142. Miller, S.A.; Myers, R.J. Correction to "Environmental Impacts of Alternative Cement Binders". Environ. Sci. Technol. 2021, 54, 677-686. [CrossRef] [PubMed]

143. Li, J.; Zhang, W.; Xu, K.; Monteiro, P.J. Fibrillar calcium silicate hydrate seeds from hydrated tricalcium silicate lower cement demand. Cem. Concr. Res. 2020, 137, 106195. [CrossRef]

144. Taylor, H.F.W. Cement Chemistry; Thomas Telford: London, UK, 1997.

145. Clavier, K.A.; Paris, J.M.; Ferraro, C.C.; Townsend, T.G. Opportunities and challenges associated with using municipal waste incineration ash as a raw ingredient in cement production-A review. Resour. Conserv. Recycl. 2020, 160, 104888. [CrossRef]

146. Geng, G.; Barbotin, S.; Shakoorioskooie, M.; Shi, Z.; Leemann, A.; Sanchez, D.F.; Grolimund, D.; Wieland, E.; Dähn, R. An in-situ 3D micro-XRD investigation of water uptake by alkali-silica-reaction (ASR) product. Cem. Concr. Res. 2021, 141, 106331. [CrossRef]

147. Mut, M.D.M.C.; Nørskov, L.K.; Frandsen, F.J.; Glarborg, P.; Dam-Johansen, K. Review: Circulation of Inorganic Elements in Combustion of Alternative Fuels in Cement Plants. Energy Fuels 2015, 29, 4076-4099. [CrossRef]

148. IEA. Technology Roadmap —Low-Carbon Transition in the Cement Industry; International Energy Agency: Paris, France, 2018.

149. Wang, L.; Jamro, I.A.; Chen, Q.; Li, S.; Luan, J.; Yang, T. Immobilization of trace elements in municipal solid waste inciner-ator (MSWI) fly ash by producing calcium sulphoaluminate cement after carbonation and washing. Waste Manag. Res. 2016, 34, 184-194. [CrossRef]

150. Ghouleh, Z.; Shao, Y.; Zhang, S. Performance of eco-concrete made from waste-derived eco-cement. J. Clean. Prod. 2021, 289, 125758. [CrossRef]

151. Wu, K.; Shi, H.; De Schutter, G.; Guo, X.; Ye, G. Preparation of alinite cement from municipal solid waste incineration fly ash. Cem. Concr. Compos. 2012, 34, 322-327. [CrossRef]

152. Guo, X.; Shi, H.; Wu, K.; Ju, Z.; Dick, W.A. Performance and risk assessment of alinite cement-based materials from mu-nicipal solid waste incineration fly ash (MSWIFA). Mater. Struct. 2016, 49, 2383-2391. [CrossRef]

153. Ashraf, M.S.; Ghouleh, Z.; Shao, Y. Production of eco-cement exclusively from municipal solid waste incineration residues. Resour. Conserv. Recycl. 2019, 149, 332-342. [CrossRef]

154. Juenger, M.C.; Snellings, R.; Bernal, S.A. Supplementary cementitious materials: New sources, characterization, and performance insights. Cem. Concr. Res. 2019, 122, 257-273. [CrossRef]

155. Li, C.; Zhu, H.; Wu, M.; Wu, K.; Jiang, Z. Pozzolanic reaction of fly ash modified by fluidized bed reactor-vapor deposition. Cem. Concr. Res. 2017, 92, 98-109. [CrossRef]

156. Berodier, E.; Scrivener, K. Understanding the Filler Effect on the Nucleation and Growth of C-S-H. J. Am. Ceram. Soc. 2014, 97, 3764-3773. [CrossRef]

157. Peys, A.; Douvalis, A.P.; Hallet, V.; Rahier, H.; Blanpain, B.; Pontikes, Y. Inorganic polymers from $\mathrm{CaO}_{-} \mathrm{FeOx}-\mathrm{SiO}_{2}$ slag: The start of oxidation of Fe and the formation of a mixed valence binder. Front. Mater. 2019, 6, 212. [CrossRef]

158. Diaz-Loya, I.; Juenger, M.; Seraj, S.; Minkara, R. Extending supplementary cementitious material resources: Reclaimed and remediated fly ash and natural pozzolans. Cem. Concr. Compos. 2019, 101, 44-51. [CrossRef]

159. Bie, R.; Chen, P.; Song, X.; Ji, X. Characteristics of municipal solid waste incineration fly ash with cement solidification treatment. J. Energy Inst. 2016, 89, 704-712. [CrossRef]

160. Quina, M.J.; Bordado, J.; Quinta-Ferreira, R.M. Recycling of air pollution control residues from municipal solid waste incineration into lightweight aggregates. Waste Manag. 2014, 34, 430-438. [CrossRef] [PubMed]

161. Jin, Q.; Perry, L.N.; Bullard, J.W. Temperature dependence of gypsum dissolution rates. Cem. Concr. Res. 2020, $129,105969$. [CrossRef]

162. Li, Q.G.; Ge, Y.; Geng, G.; Bae, S.; Monteiro, P.J.M. CaCl2-Accelerated Hydration of Tricalcium Silicate: A STXM Study Combined with 29Si MAS NMR. J. Nanomater. 2015, 2015, 412. [CrossRef]

163. Shi, H.-S.; Kan, L.-L. Characteristics of municipal solid wastes incineration (MSWI) fly ash-cement matrices and effect of mineral admixtures on composite system. Constr. Build. Mater. 2009, 23, 2160-2166. [CrossRef] 
164. Garcia-Lodeiro, I.; Carcelen-Taboada, V.; Fernández-Jiménez, A.; Palomo, A. Manufacture of hybrid cements with fly ash and bottom ash from a municipal solid waste incinerator. Constr. Build. Mater. 2016, 105, 218-226. [CrossRef]

165. Jurič, B.; Hanžič, L.; Ilić, R.; Samec, N. Utilization of municipal solid waste bottom ash and recycled aggregate in concrete. Waste Manag. 2006, 26, 1436-1442. [CrossRef]

166. Zhang, T.; Zhao, Z. Optimal Use of MSWI Bottom Ash in Concrete. Int. J. Concr. Struct. Mater. 2014, 8, 173-182. [CrossRef]

167. Zacco, A.; Borgese, L.; Gianoncelli, A.; Struis, R.P.W.J.; Depero, L.E.; Bontempi, E. Review of fly ash inertisation treatments and recycling. Environ. Chem. Lett. 2014, 12, 153-175. [CrossRef]

168. Keppert, M.; Siddique, J.A.; Pavlík, Z.; Černý, R. Wet-Treated MSWI Fly Ash Used as Supplementary Cementitious Material. Adv. Mater. Sci. Eng. 2015, 2015, 842807. [CrossRef]

169. Lee, T.-C.; Wang, W.-J.; Shih, P.-Y.; Lin, K.-L. Enhancement in early strengths of slag-cement mortars by adjusting basicity of the slag prepared from fly-ash of MSWI. Cem. Concr. Res. 2009, 39, 651-658. [CrossRef]

170. Lin, K.; Wang, K.; Tzeng, B.; Lin, C. The reuse of municipal solid waste incinerator fly ash slag as a cement substitute. Resour. Conserv. Recycl. 2003, 39, 315-324. [CrossRef]

171. Lee, T.-C.; Chang, C.-J.; Rao, M.-K.; Su, X.-W. Modified MSWI ash-mix slag for use in cement concrete. Constr. Build. Mater. 2011, 25, 1513-1520. [CrossRef]

172. Lee, T.-C.; Rao, M.-K. Recycling municipal incinerator fly- and scrubber-ash into fused slag for the substantial replacement of cement in cement-mortars. Waste Manag. 2009, 29, 1952-1959. [CrossRef] [PubMed]

173. Shih, P.-Y.; Lee, P.-H.; Nian, K.-J.; Lee, T.-C. Characterization of a mortar made with cement and slag vitrified from a MSWI ash-mix and CMP sludge. Constr. Build. Mater. 2013, 38, 22-30. [CrossRef]

174. Stumm, A.; Garbev, K.; Beuchle, G.; Black, L.; Stemmermann, P.; Nüesch, R. Incorporation of zinc into calcium silicate hy-drates, Part I: Formation of CSH (I) with C/S=2/3 and its isochemical counterpart gyrolite. Cem. Concr. Res. 2005, 35, 1665-1675. [CrossRef]

175. Rose, J.; Moulin, I.; Hazemann, J.-L.; Masion, A.; Bertsch, P.M.; Bottero, J.-Y.; Mosnier, F.; Haehnel, C. X-ray absorption spectroscopy study of immobilization processes for heavy metals in calcium silicate hydrates: 1. Case of lead. Langmuir 2000, 16, 9900-9906. [CrossRef]

176. Provis, J.; Palomo, A.; Shi, C. Advances in understanding alkali-activated materials. Cem. Concr. Res. 2015, 78, 110-125. [CrossRef]

177. Gong, K.; White, C. Impact of chemical variability of ground granulated blast-furnace slag on the phase formation in alkaliactivated slag pastes. Cem. Concr. Res. 2016, 89, 310-319. [CrossRef]

178. Zhu, X.; Zhang, M.; Yang, K.; Yu, L.; Yang, C. Setting behaviours and early-age microstructures of alkali-activated ground granulated blast furnace slag (GGBS) from different regions in China. Cem. Concr. Compos. 2020, 114, 103782. [CrossRef]

179. Zhu, X.; Zhang, M.; Yang, Y.; Yang, K.; Wu, F.; Li, Q.; Yu, L.; Yang, C.; Basheer, M. Understanding the aqueous phases of alkali-activated slag paste under water curing. Adv. Cem. Res. 2021, 33, 59-73. [CrossRef]

180. Cheng, T.; Lee, M.; Ko, M.; Ueng, T.; Yang, S. The heavy metal adsorption characteristics on metakaolin-based geopolymer. Appl. Clay Sci. 2012, 56, 90-96. [CrossRef]

181. Shi, C.; Jimenez, A.M.F.; Palomo, A. New cements for the 21st century: The pursuit of an alternative to Portland cement. Cem. Concr. Res. 2011, 41, 750-763. [CrossRef]

182. Jiang, N.; Shang, R.; Heijman, S.G.; Rietveld, L. High-silica zeolites for adsorption of organic micro-pollutants in water treatment: A review. Water Res. 2018, 144, 145-161. [CrossRef]

183. Ma, B.; Fernandez-Martinez, A.; Mancini, A.; Lothenbach, B. Spectroscopic investigations on structural incorporation pathways of FeIII into zeolite frameworks in cement-relevant environments. Cem. Concr. Res. 2021, 140, 106304. [CrossRef]

184. Provis, J.L. Alkali-activated materials. Cem. Concr. Res. 2018, 114, 40-48. [CrossRef]

185. Ke, X.; Bernal, S.A.; Provis, J.L. Controlling the reaction kinetics of sodium carbonate-activated slag cements using calcined layered double hydroxides. Cem. Concr. Res. 2016, 81, 24-37. [CrossRef]

186. Huang, G.; Ji, Y.; Zhang, L.; Li, J.; Hou, Z. The influence of curing methods on the strength of MSWI bottom ash-based al-kali-activated mortars: The role of leaching of $\mathrm{OH}-$ and free alkali. Constr. Build. Mater. 2018, 186, 978-985. [CrossRef]

187. Bernal, S.A.; Rodríguez, E.D.; Kirchheim, A.P.; Provis, J.L. Management and valorisation of wastes through use in producing alkali-activated cement materials. J. Chem. Technol. Biotechnol. 2016, 91, 2365-2388. [CrossRef]

188. Zhu, W.; Chen, X.; Struble, L.J.; Yang, E.-H. Quantitative characterization of aluminosilicate gels in alkali-activated incineration bottom ash through sequential chemical extractions and deconvoluted nuclear magnetic resonance spectra. Cem. Concr. Compos. 2019, 99, 175-180. [CrossRef]

189. Chen, Z.; Liu, Y.; Zhu, W.; Yang, E.-H. Incinerator bottom ash (IBA) aerated geopolymer. Constr. Build. Mater. 2016, $112,1025-1031$. [CrossRef]

190. Wongsa, A.; Boonserm, K.; Waisurasingha, C.; Sata, V.; Chindaprasirt, P. Use of municipal solid waste incinerator (MSWI) bottom ash in high calcium fly ash geopolymer matrix. J. Clean. Prod. 2017, 148, 49-59. [CrossRef]

191. Song, Y.; Li, B.; Yang, E.-H.; Liu, Y.; Ding, T. Feasibility study on utilization of municipal solid waste incineration bottom ash as aerating agent for the production of autoclaved aerated concrete. Cem. Concr. Compos. 2015, 56, 51-58. [CrossRef]

192. Rożek, P.; Król, M.; Mozgawa, W. Solidification/stabilization of municipal solid waste incineration bottom ash via auto-clave treatment: Structural and mechanical properties. Constr. Build. Mater. 2019, 202, 603-613. [CrossRef] 
193. Qiao, X.; Tyrer, M.; Poon, C.; Cheeseman, C. Novel cementitious materials produced from incinerator bottom ash. Resour. Conserv. Recycl. 2008, 52, 496-510. [CrossRef]

194. Huang, G.; Yang, K.; Chen, L.; Lu, Z.; Sun, Y.; Zhang, X.; Feng, Y.; Ji, Y.; Xu, Z. Use of pretreatment to prevent expansion and foaming in high-performance MSWI bottom ash alkali-activated mortars. Constr. Build. Mater. 2020, 245, 118471. [CrossRef]

195. Huang, G.; Yang, K.; Sun, Y.; Lu, Z.; Zhang, X.; Zuo, L.; Feng, Y.; Qian, R.; Qi, Y.; Ji, Y.; et al. Influence of NaOH content on the alkali conversion mechanism in MSWI bottom ash alkali-activated mortars. Constr. Build. Mater. 2020, 248, 118582. [CrossRef]

196. Huang, G.; Ji, Y.; Li, J.; Zhang, L.; Liu, X.; Liu, B. Effect of activated silica on polymerization mechanism and strength development of MSWI bottom ash alkali-activated mortars. Constr. Build. Mater. 2019, 201, 90-99. [CrossRef]

197. Ren, J.; Hu, L.; Dong, Z.; Tang, L.; Xing, F.; Liu, J. Effect of silica fume on the mechanical property and hydration characteristic of alkali-activated municipal solid waste incinerator (MSWI) fly ash. J. Clean. Prod. 2021, 295, 126317. [CrossRef]

198. Zheng, L.; Wang, W.; Shi, Y. The effects of alkaline dosage and Si / Al ratio on the immobilization of heavy metals in municipal solid waste incineration fly ash-based geopolymer. Chemosphere 2010, 79, 665-671. [CrossRef]

199. Liu, J.; Hu, L.; Tang, L.; Ren, J. Utilisation of municipal solid waste incinerator (MSWI) fly ash with metakaolin for preparation of alkali-activated cementitious material. J. Hazard. Mater. 2021, 402, 123451. [CrossRef]

200. Diaz-Loya, E.I.; Allouche, E.N.; Eklund, S.; Joshi, A.R.; Kupwade-Patil, K. Toxicity mitigation and solidification of municipal solid waste incinerator fly ash using alkaline activated coal ash. Waste Manag. 2012, 32, 1521-1527. [CrossRef]

201. Pera, J.; Coutaz, L.; Ambroise, J.; Chababbet, M. Use of incinerator bottom ash in concrete. Cem. Concr. Res. 1997, $27,1-5$. [CrossRef]

202. Müller, U.; Rübner, K. The microstructure of concrete made with municipal waste incinerator bottom ash as an aggregate component. Cem. Concr. Res. 2006, 36, 1434-1443. [CrossRef]

203. van der Wegen, G.; Hofstra, U.; Speerstra, J. Upgraded MSWI Bottom Ash as Aggregate in Concrete. Waste Biomass Valorization 2013, 4, 737-743. [CrossRef]

204. Forteza, R.; Far, M.; Seguí, C.; Cerdá, V. Characterization of bottom ash in municipal solid waste incinerators for its use in road base. Waste Manag. 2004, 24, 899-909. [CrossRef] [PubMed]

205. Chatziaras, N.; Psomopoulos, C.S.; Themelis, N.J. Use of waste derived fuels in cement industry: A review. Manag. Environ. Qual. Int. J. 2016, 27, 178-193. [CrossRef]

206. García-Pérez, J.; López-Abente, G.; Castelló, A.; González-Sánchez, M.; Fernández-Navarro, P. Cancer mortality in towns in the vicinity of installations for the production of cement, lime, plaster, and magnesium oxide. Chemosphere 2015, 128, 103-110. [CrossRef] [PubMed]

207. Herrero, A.; Vilella, M. 'We have a right to breathe clean air': The emerging environmental justice movement against waste incineration in cement kilns in Spain. Sustain. Sci. 2018, 13, 721-731. [CrossRef]

208. Brunner, P.H.; Rechberger, H. Waste to energy-Key element for sustainable waste management. Waste Manag. 2015, $37,3-12$. [CrossRef] [PubMed]

209. Psomopoulos, C.; Bourka, A.; Themelis, N. Waste-to-energy: A review of the status and benefits in USA. Waste Manag. 2009, 29, 1718-1724. [CrossRef] [PubMed]

210. Gursel, A.P. Life-Cycle Assessment of Concrete: Decision-Support. Tool and Case Study Application; The University of California: Berkeley, CA, USA, 2014; pp. 1-540.

211. Akhtar, A.; Sarmah, A.K. Construction and demolition waste generation and properties of recycled aggregate concrete: A global perspective. J. Clean. Prod. 2018, 186, 262-281. [CrossRef]

212. Yin, K.; Chan, W.P.; Dou, X.; Ren, F.; Chang, V.W.-C. Cr, Cu, Hg and Ni release from incineration bottom ash during uti-lization in land reclamation-based on lab-scale batch and column leaching experiments and a modeling study. Chemosphere 2018, 197, 741-748. [CrossRef] [PubMed] 